\title{
بغية القاصد في أسانيل سبعة ابن مجاهد
}

الباحثُة/ معاء تامة عليا حجازيا

المقدمة:

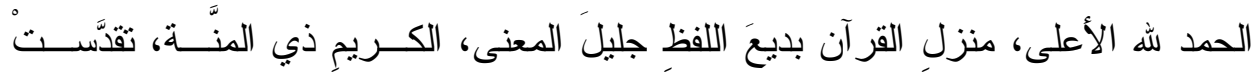

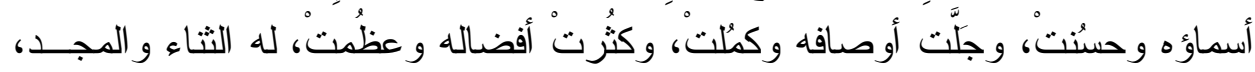

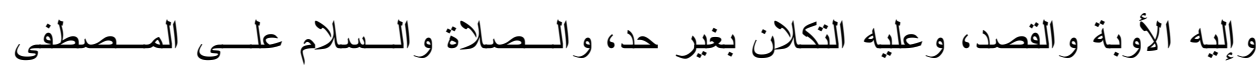

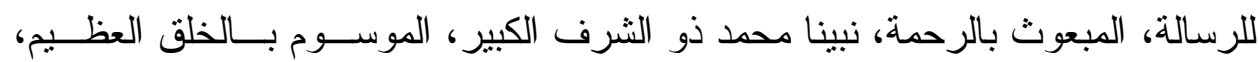
صلو ات الله وسلامه عليه. وبعد:

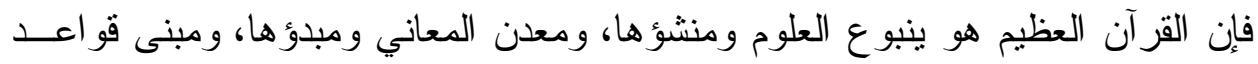

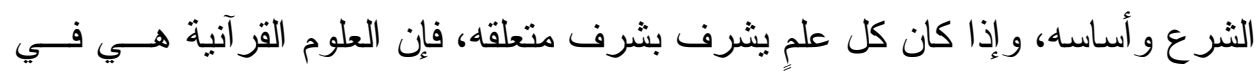

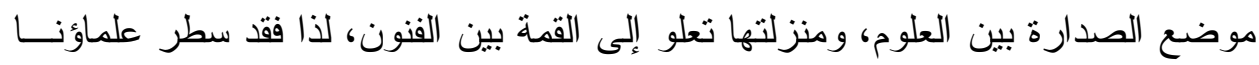

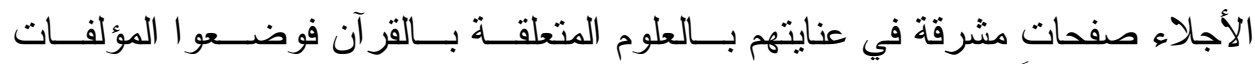

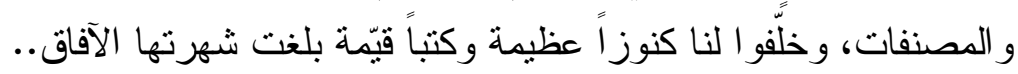

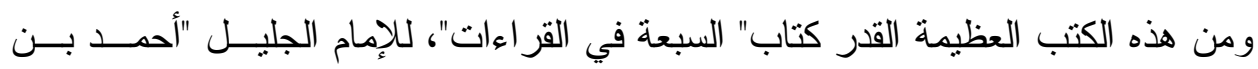

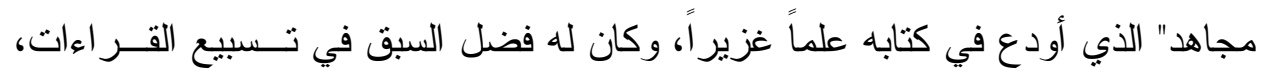

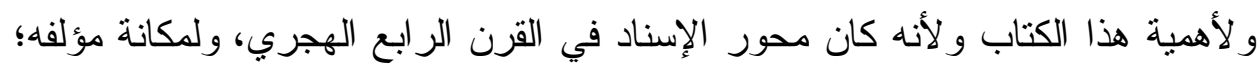

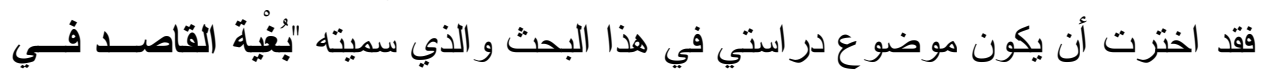

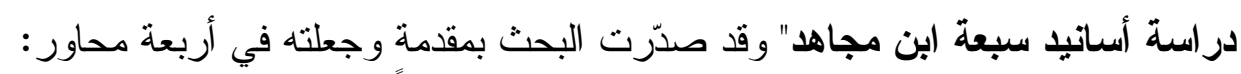

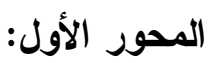

در اسة الكتاب ومؤلفه، ويشتمل على الاول: الكت

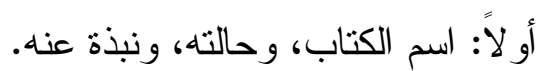
ثانيا: اسم مؤلفه، ومولده، ونشأته، وشيوخه، وتله، وتلاميذه، ومؤلفاته، ووفاته. 


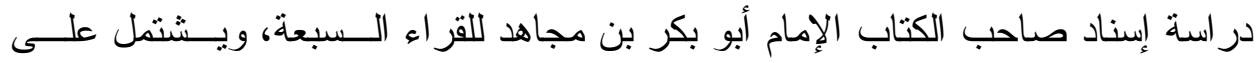
در اسة رجال الإسناد من حيث: (الاسم، الثيوخ، التلاميذ، الوفاة، حكم العلماء عليهم). المحور الثالث: درالث

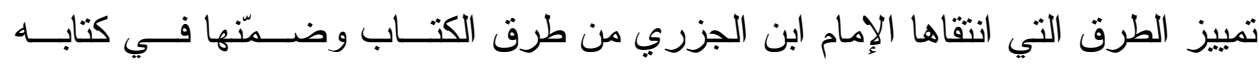
النشر

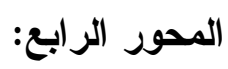
منهج المصنف فيما ذكره من غير طرقه في الكتاب، وفي ذكره للأوجه غير المقــروء

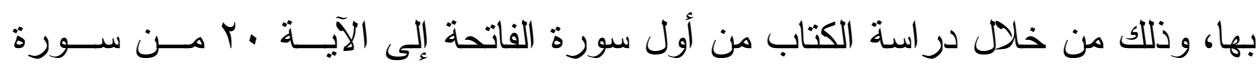
البقرة.

وسأتبع في در اسة المحاور السابقة المنهج التالي:

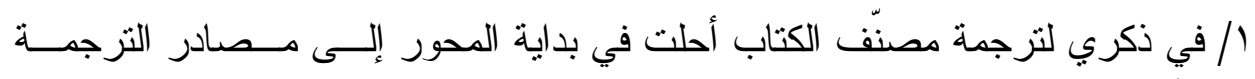
إجمالاً. / / أوردت الإسناد كما ذكره المصنف، بلفظه، وبترتيب قر ائه.

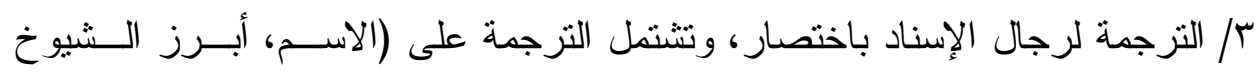
و التلاميذ، حكم العلماء عليه، وفاته) ما أمكن في ذللك كله.

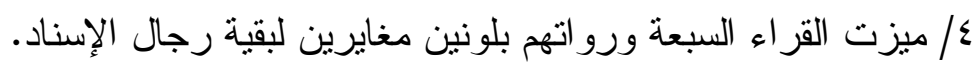

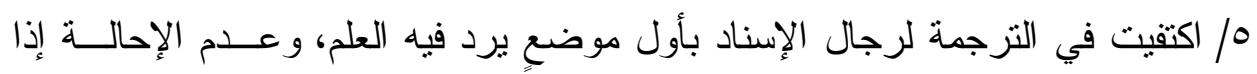

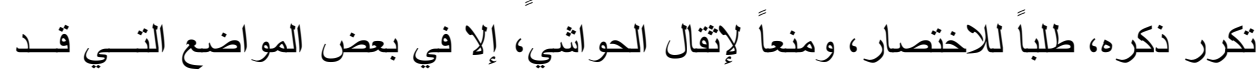
يقع فيها إثنكال.

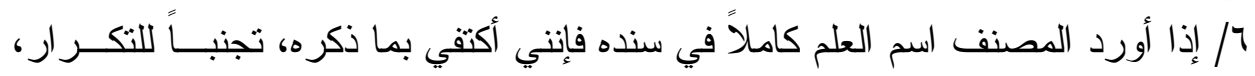
أما إذا جاء الاسم مبهماً أو مختصر أ فإنني أذكره.

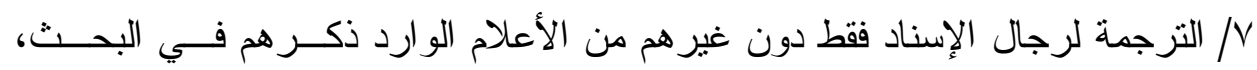

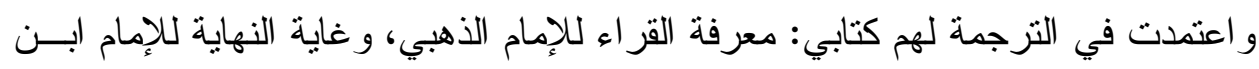
الجزري.

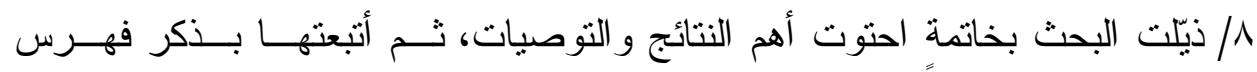

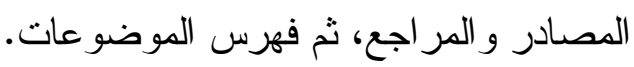




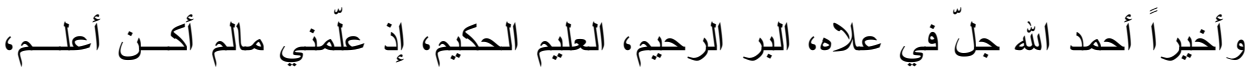

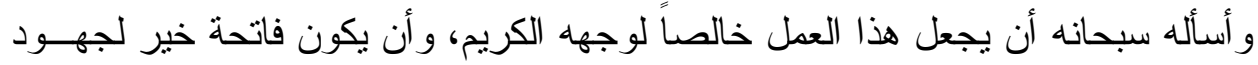

كبيرة. 


\section{المحور الأول}

در اسة الكتاب ومؤلفه

أولاً:در اسة الكتاب:

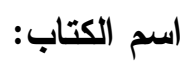

كتاب السبعة، وقد ذكر محقق الكتاب د/ شوقي ضيف اسمين آخرين وجدت في نسـخ الكتاب التي اعتمدها للتحقيق: / / "كتاب السبعة لابن مجاهد المسند المقرئ"، ورد في نسخة مكتبــــة إبــر اهيم أفنــدي باستانبول. r/ "كتاب في اختلاف القر اء السبعة"، ورد في النسخة التونسية. و هناك اسم ثالثٌ أطلقه بعض القدماء " السبعة في منازل القر اء".

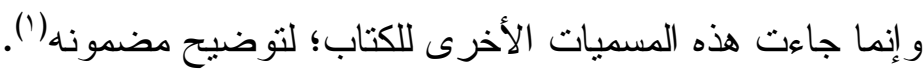

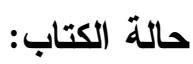

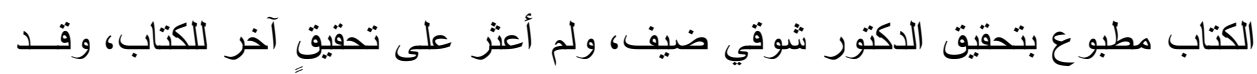

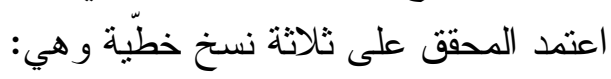
/ / / نسخة المكتبة الوطنية بتونس.

/ / نسخة مكتبة إبر اهيم أفندي الملحقة بالمكتبة السليمانية باستتابول، تركيا. ץ/ نسخة مكتبة تشستربتي، دبلن، إيرلندا.

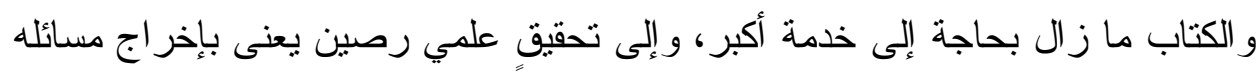
ودر اسة أسانيده در اسة جيدة.

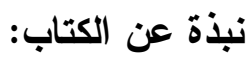

اختار المصنف سبعة من أئمة القر اء في أمصار الخمسة، هي أهم الأمصار التي حملت

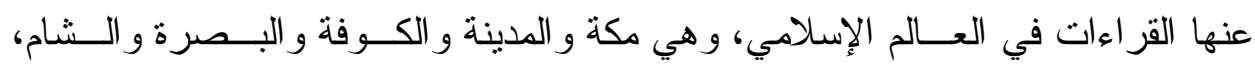

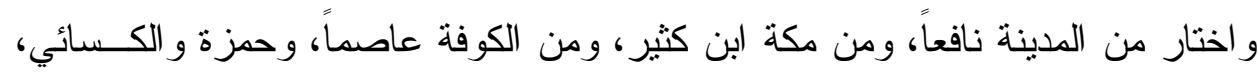

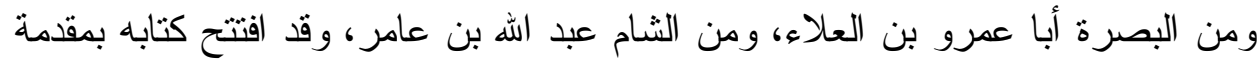

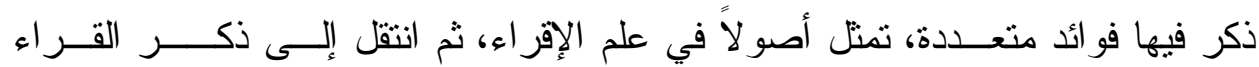

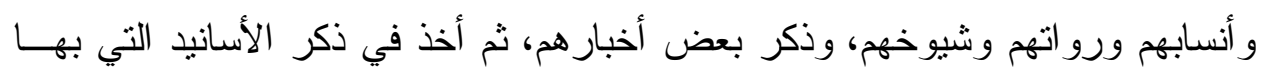




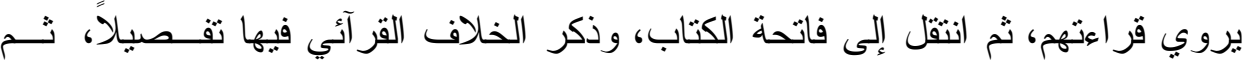

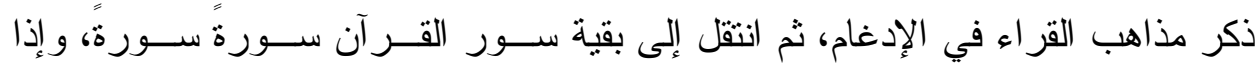

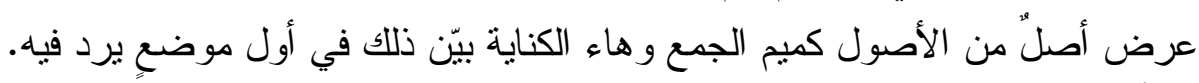
ثانياً:در اسة مؤلف الكتاب(') من الاصول اسمهل ونسبه:

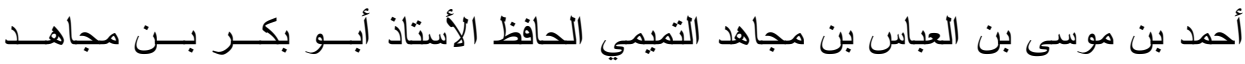
البغدادي.

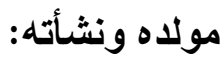

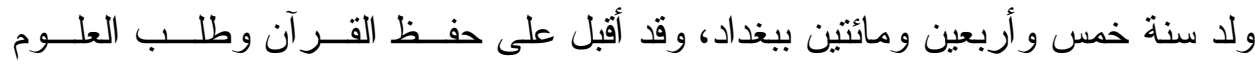

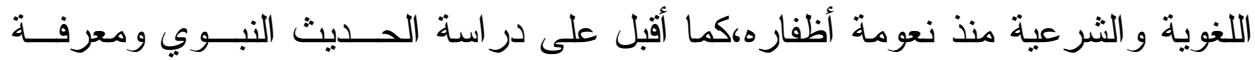

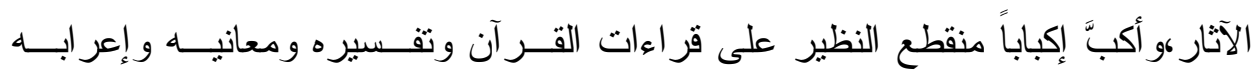

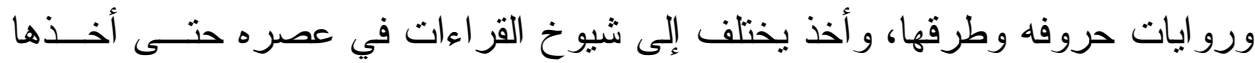
جميعاً. شيوخه: قر أ على شيوخٍ كثر ، أذكر منهم: / / عبد الرحمن بن عبدوس، وقد قر أ عليه عشرين ختمة.

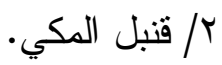
r/ إسحاق بن أحمد الخز اعي.

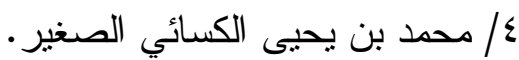
/ أحمد بن يحيى بن ثعلب. 7/ / موسى بن إسحاق الأنصاري. / إدريس بن عبد الكريم الحداد.

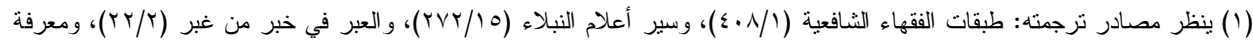

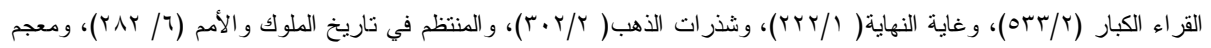

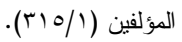




\section{تلاميذه:}

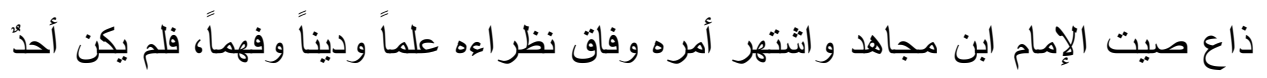

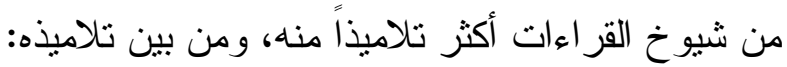

/ / إبر اهيم بن أحمد بن الحطاب.

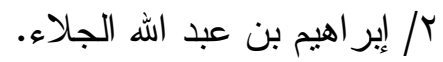

r/ الحسين بن خالويه النحوي.

ع/ محمد بن بشر الثارب.

/ / أحمد بن نصر بن الثذائي.

/ / إسماعيل بن القاسم الصالحي.

مؤلفاته:

/ / قر اعة النبي صلى الله عليه وسلم.

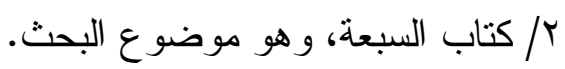

r/ كتاب الثو اذ في القر اءات.

ع/ كتاب انفر ادات القر اء السبعة.

م/ قر اءة علي بن أبي طالب.

وفاته:

توفي يوم الأربعاء وقت الظهر في العشرين من شعبان سنة ؟ ؟بهـ. 


\section{المحور الثاني \\ دراسة إسناد مصنف الكتاب إلى القراء السبعة}

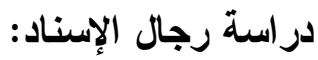

قال الإمام ابن مجاهد في باب سمّاه " ذكر الأسانيد التي نقلت إلينـا القراعة عن أئمسـة

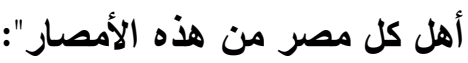

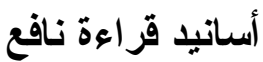

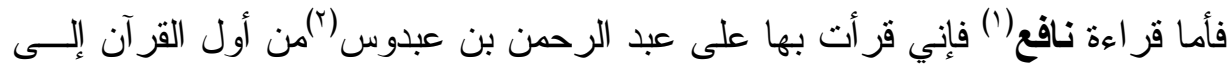

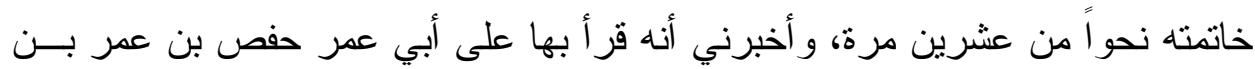

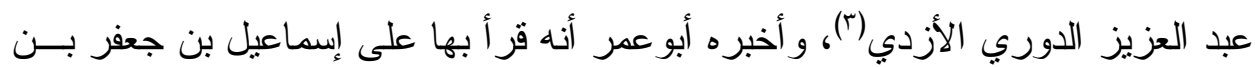
أبي كثير الأنصاري(؛)، و أخبره إسماعيل أنه قر أ بها على ألى نافع.

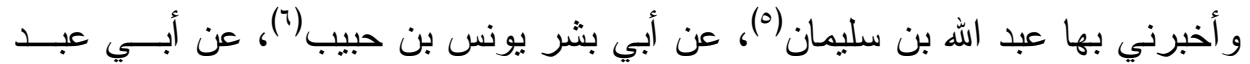

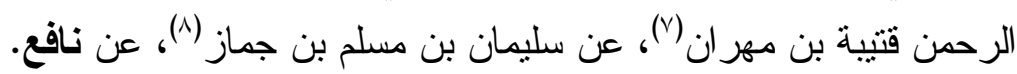

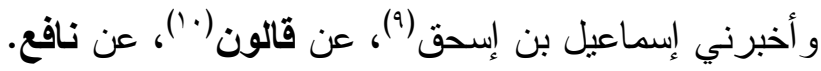

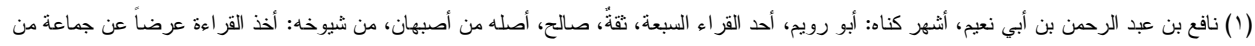

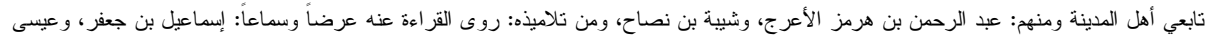

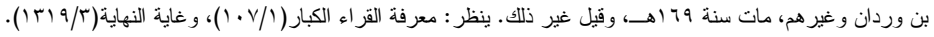

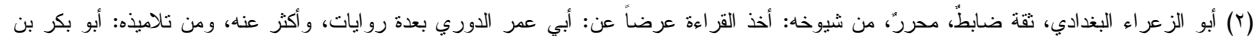

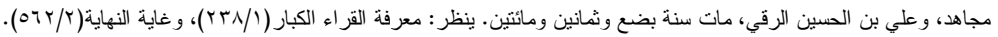

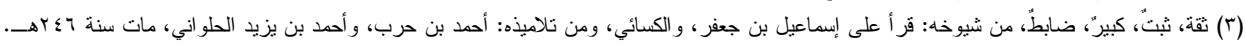

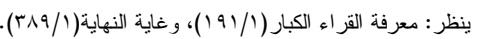

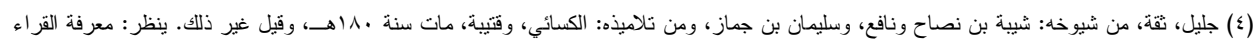

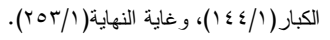

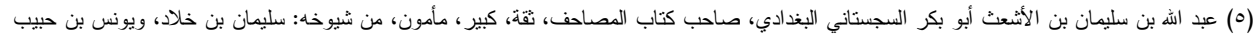

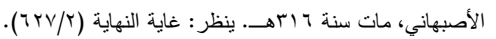

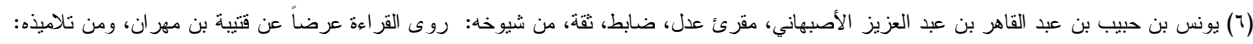

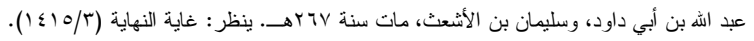

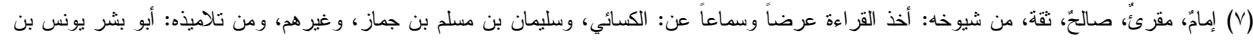

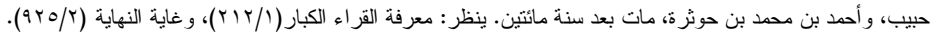

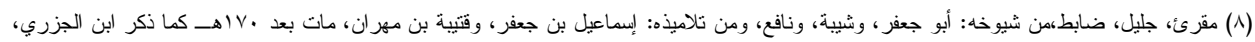

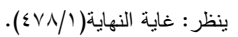

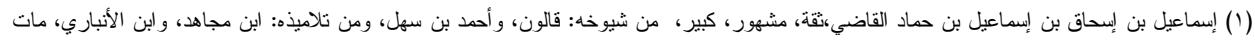

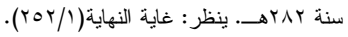

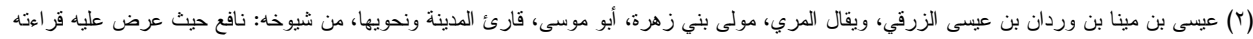

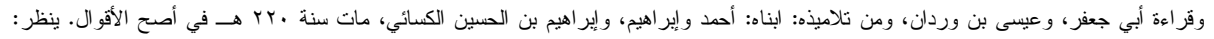

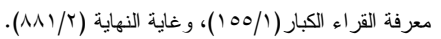


و أخبرني الأشناني الحسن بن علي بن مالك(')، عن أحمد بن صالح(؟)، عن قالون، عن

و أخبرني بها الحسن بن أبي مهران(")، عن الحلواني(؛)، عن قالون، عن نافع.

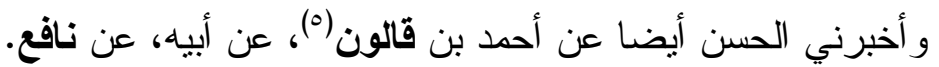

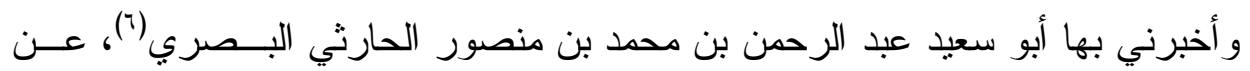

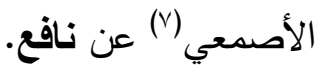
و أخبرني الأشناني الحسن بن علي، عن أحمد بن صالح، عن عثمان بن سعيد ويلقّـبـ بورش (^)، عن نافع.

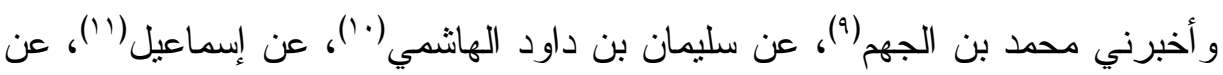
وعن أبي نوبة(r)'، عن الكسائي (')، عن إسماعيل، عن نافع .

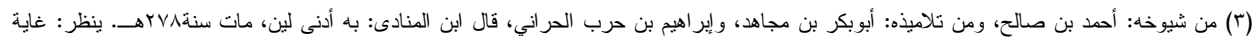

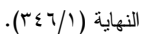
(؛) أحمد بن صالح الإمام الحافظ، أبو جعفر المصري، أحد الأعلام، من شيوخه: قر أ على ورش، وقالون، وله عن كل منهما رواية، وعلى إسماعيل بن أبي

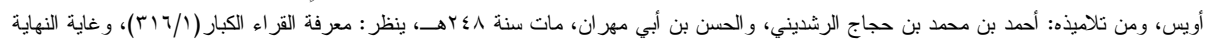

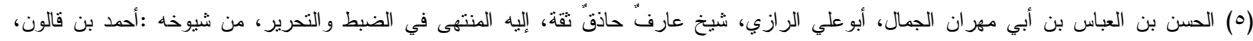

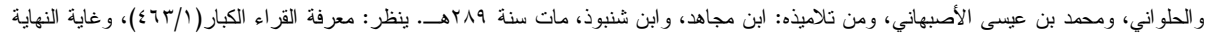
. (1) (1)

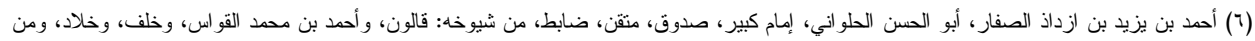

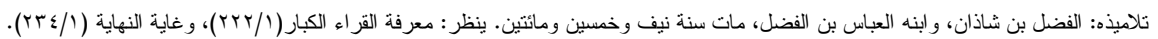

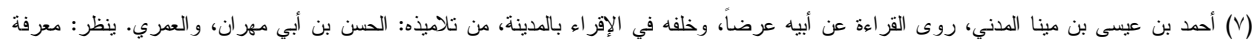

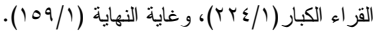

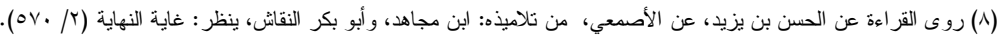

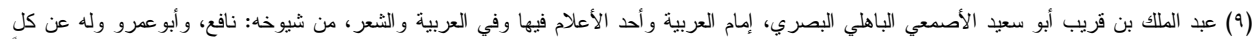

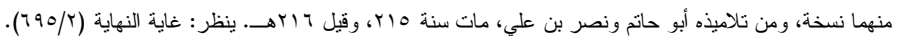

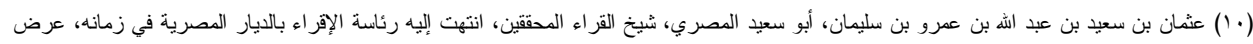

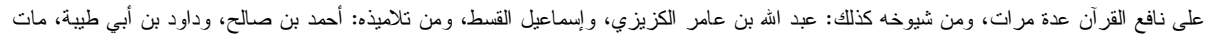

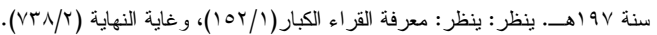

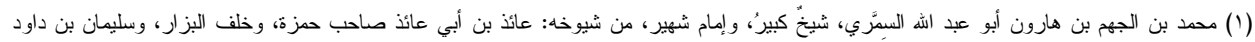

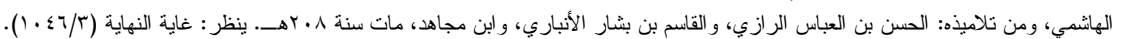

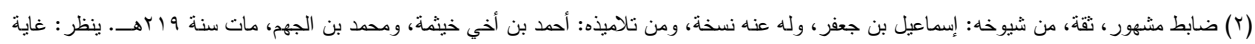
النهاية (Y (

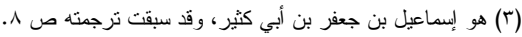

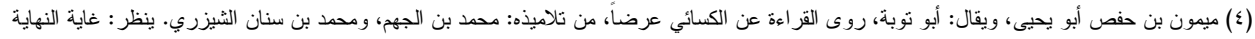


وأخبرني محمد بن الفرج(r)، عن محمد بن إسحق المسيبي(')، عن أبيه(')، عن نافع. وأخبرني أحمد بن زهير (0)، و إدريس(7)، عن خلف(")، عن إسحق الدسيبي، عن نافع. و أخبرني محمد بن يحيى الكسائي()، عن أبي الحارث الليث بن خالــــ(9)، عـن أبــي عمارة) (1) عن يعقوب بن جعفر (')، عن نافع. وعن أبي الحارث عن نافع، وعن إسحق عن نافع.

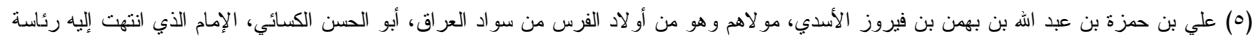

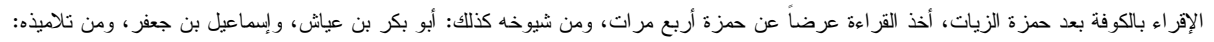

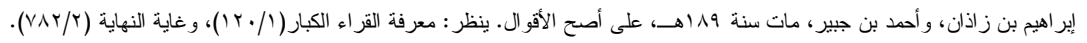

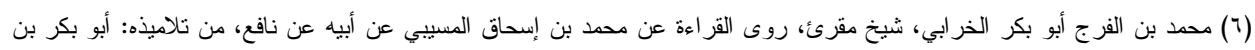

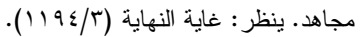

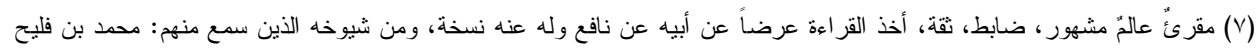

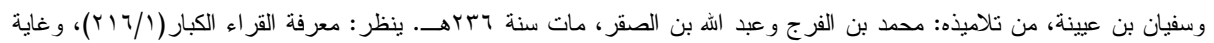

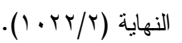

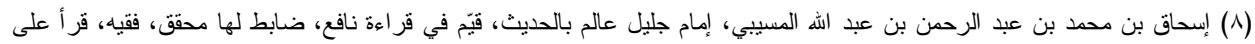

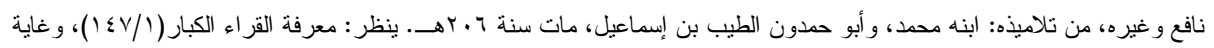

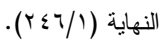
(9) أحمد بن زهير بن حرب الإمام أبو بكر بن أبي خيثمة البغادي، صاحب التاريخ، مشهور كبير ، روى القرعة عن أبيه، ومن شيوخه:

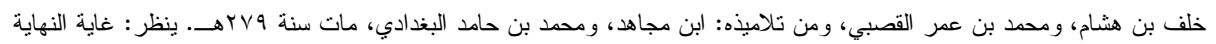

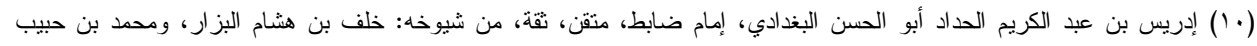

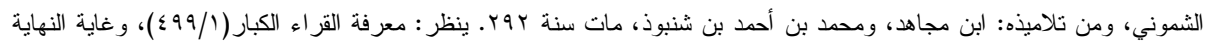
(1') خلف بن هشام بن ثعلب بن خلف البزار البغادي، أحد القراء العشرة وأحد الرواة عن سليم عن حمزة، كان ثقة كبير از اهداً عالماً.

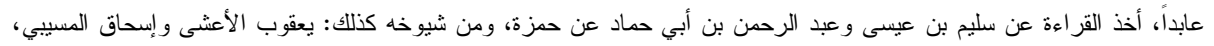

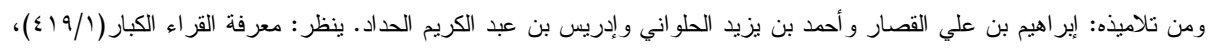

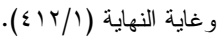

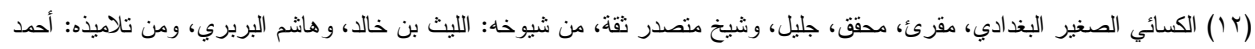

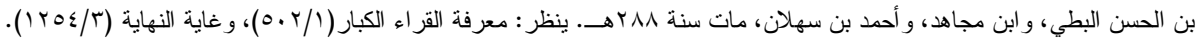

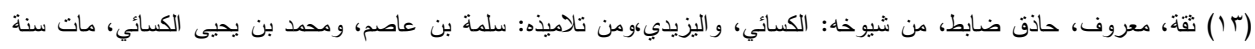

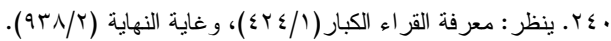

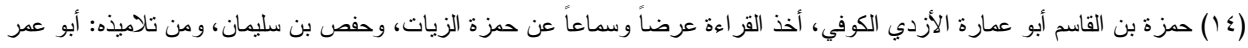

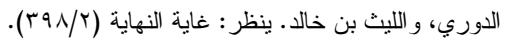




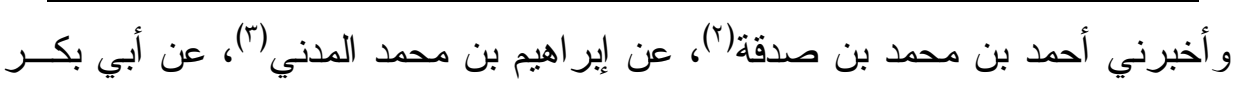
بن أبي أويس، وهو أبو بكر الأصبحي ابن أخت ماللك بن أنس (؛)، عن نافع.

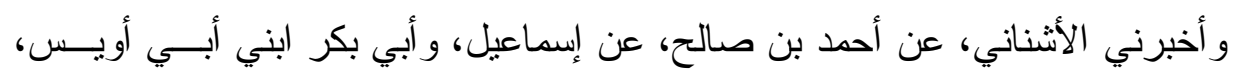
عن نافع. و أخبرني الحارث بن محمد بن أبي أسامة(ه)، عن محمد بن سعد(")، عن محمــد بـن

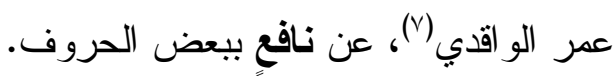
قال أبو بكر : وأخذت عامة رواية محمد بن عمر ، من كتاب محمد بـن سـعد، عـن لبعن محمد بن عمر - محر

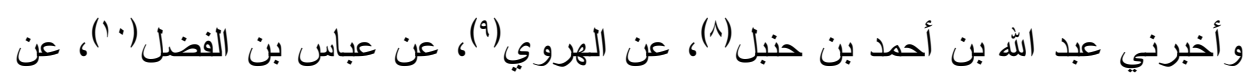

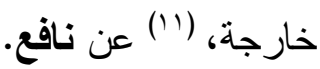
و أخبرني أبو شبل عبيد الله بن عبد الرحمن الواقدي(')، عن أبيه، عن ابن عيـاش(؟)، عن خارجة، عن نافع.

(1) يعقوب بن جعفر بن أبي كثير الأنصاري المدني، أخو إسماعيل، روى القراءة عرضاً عن سليمان بن جماز ونافع، من تلاميذه: أبو

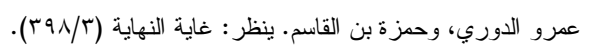

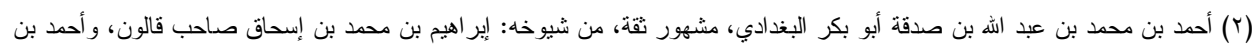

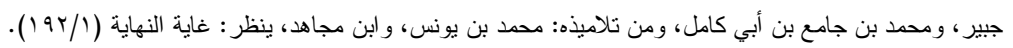

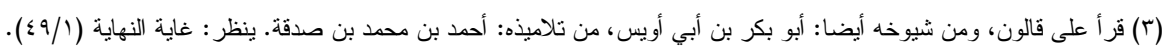

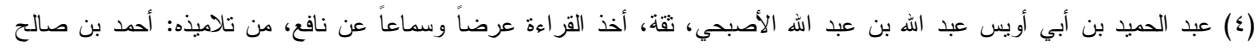

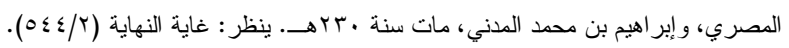

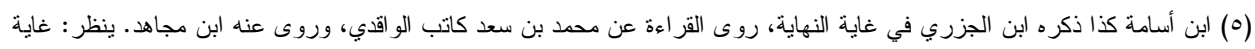

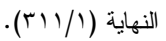
(†) محمد بن سعد أبو عبد الله البغدادي كاتب الو اقدي، حافظ مشهور ، روى عن محمد بن عمر الواقدي، ومن تلاميذه: الحارث بن أسامة،

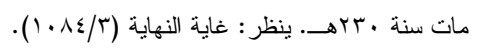

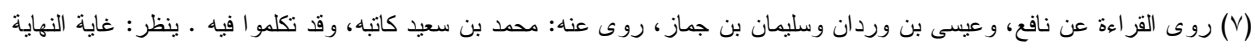
$\cdot(1 \cdot \Lambda \varepsilon / \Gamma)$

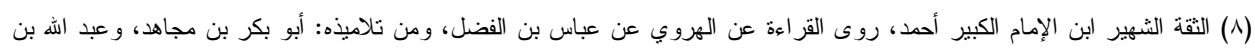

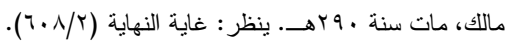

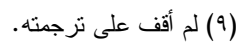

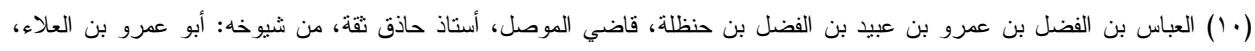

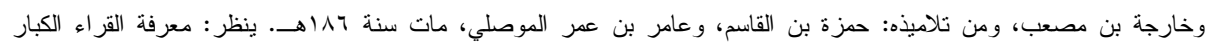

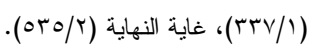

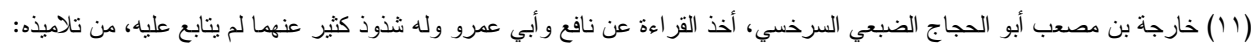

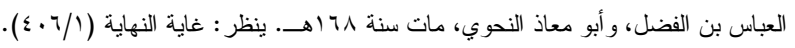


و أخبرني محمد بن يحيى الكسائي، عن أبي الحارث، عن أبي عمارة، عن الزبير بـن عامر (r) أ)، عن نافع.

و أخبرني محمد بن عبد اللها()، عن يونس بن عبد الأعلى (0)، عن ورش وسـقلاب(")، بحروف منها عن نافع.

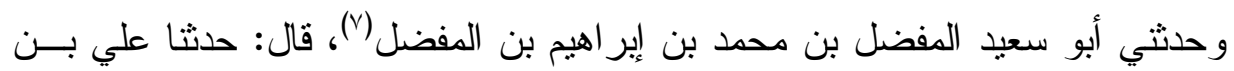

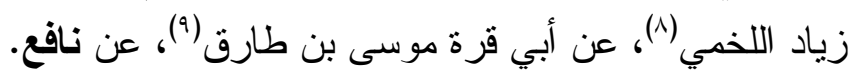

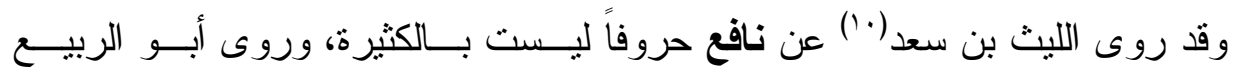

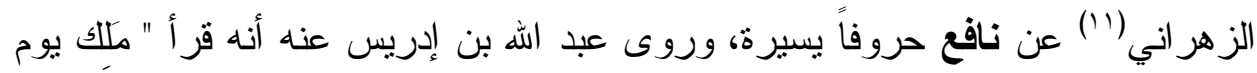

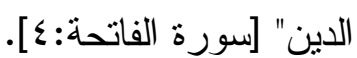

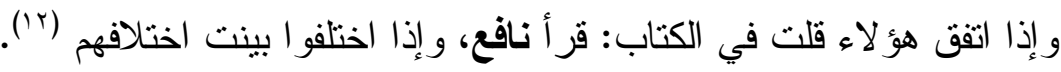
أسانيد قراعة ابن كثير

(r) شيخ مشهور ، روى عن أبيه عن الكسائي، وعن أحمد بن منصور عن الكسائي، روى القراءة عنه ابن مجاهذ و ابن الأنباري، و النقاش.

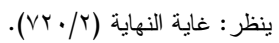

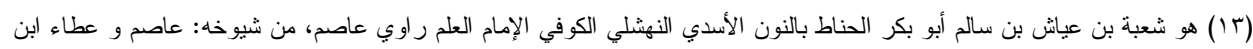

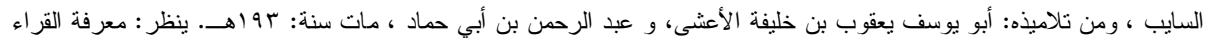

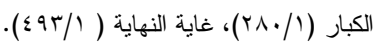

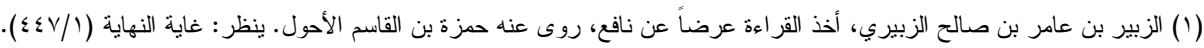

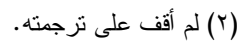

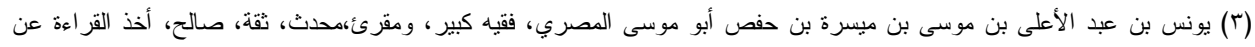

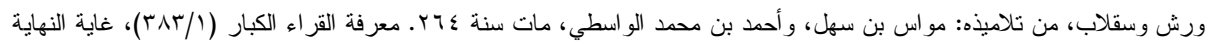
( (1 $117 / \Gamma)$ (ع) سقلاب بن شيبة أبو سعيد المصري، قر أ القر آن عرضاً على نافع، وروى عنه كتاب الثمام، وكان يقرئ بمصر مع ورش، من تثاميذه:

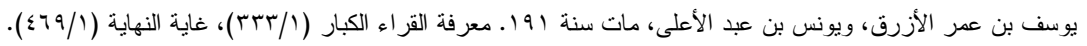

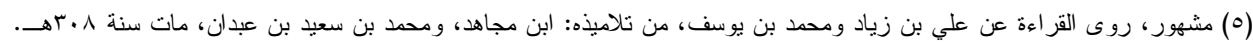

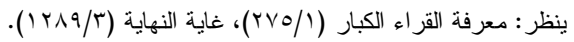

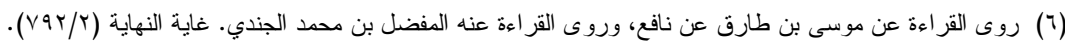

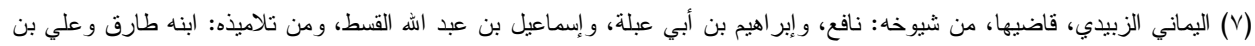

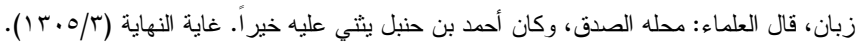

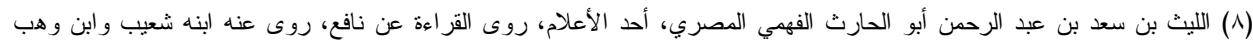

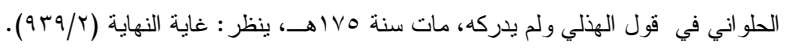

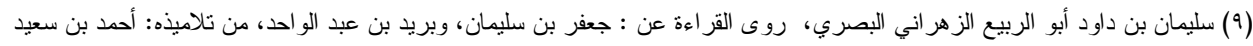

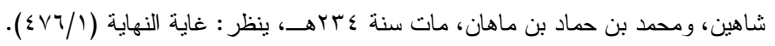

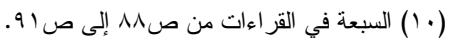




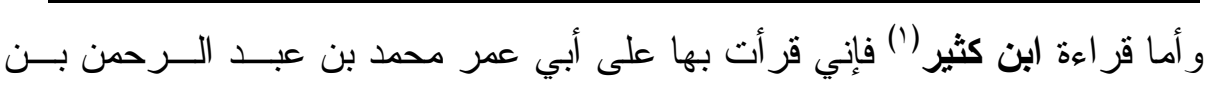

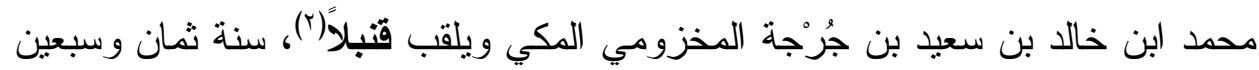

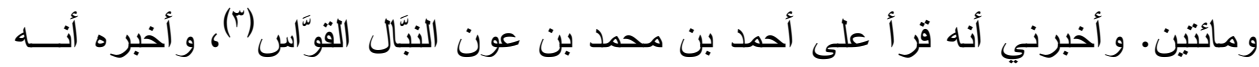

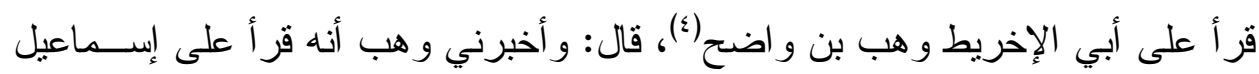

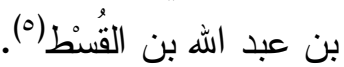

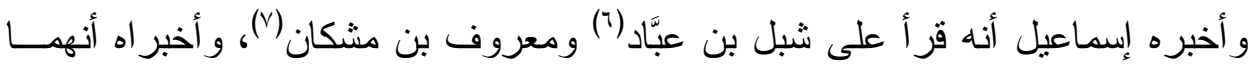
قر آ على ابن كثير رحمه الله تعالى.

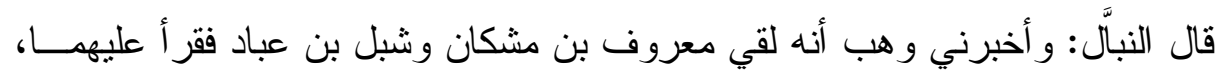
و أخبر اه بهذا الإسناد.

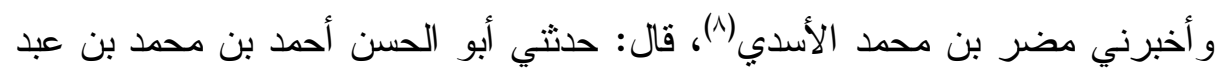

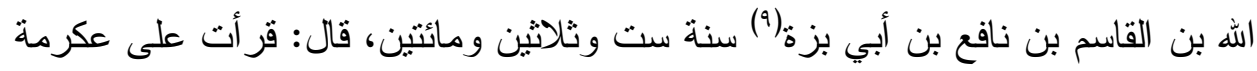

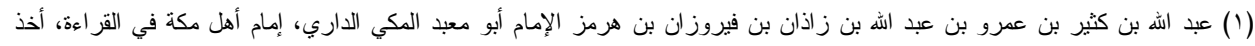

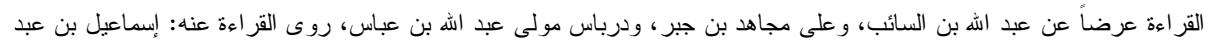

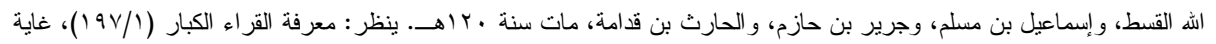

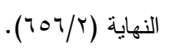

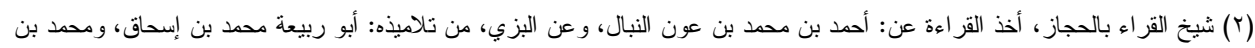

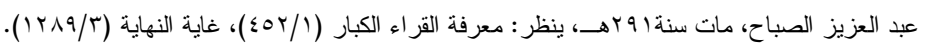

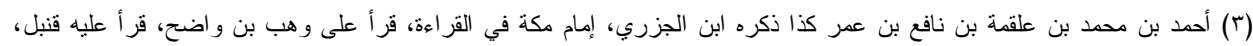

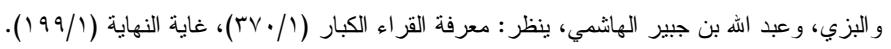

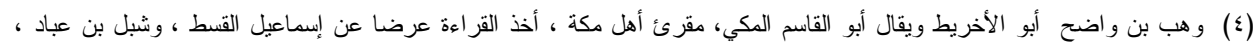

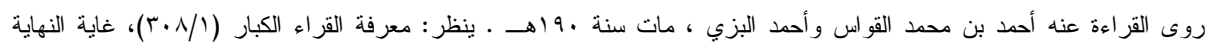

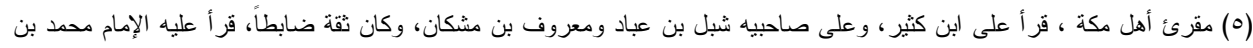

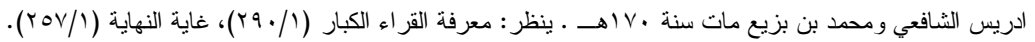

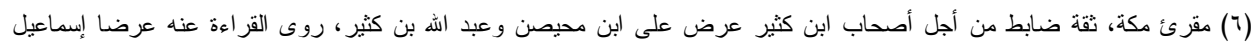

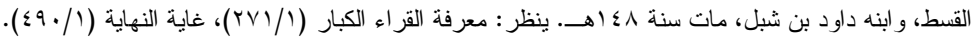

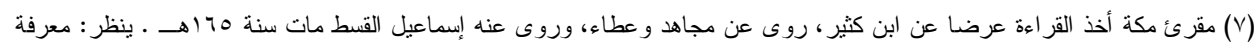

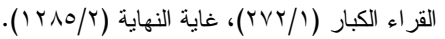

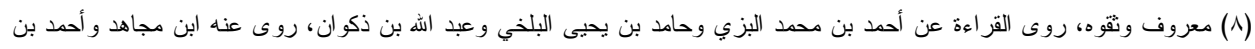

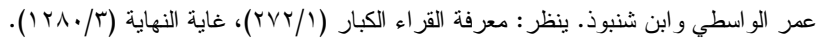

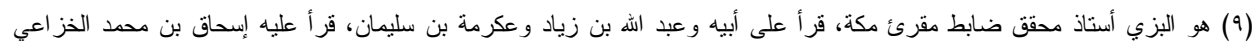

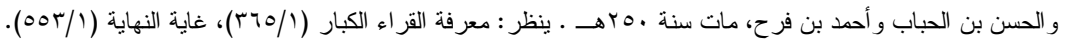


عكرمة بن سليمان بن كثير بن عامر مولى جبير بن شيبة الحجبي (')، قـال: وأخبرنــي

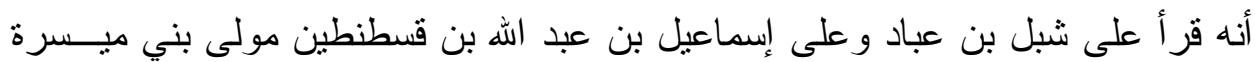

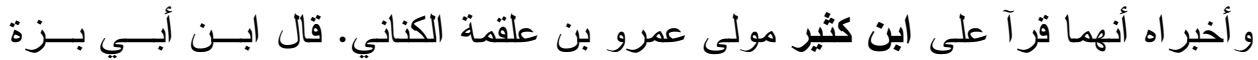

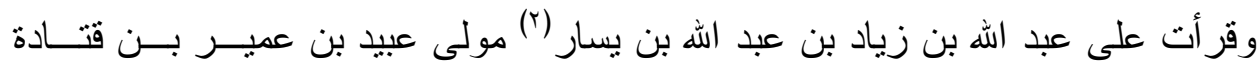
الليثي. وقال :أخبرني بهذا الإسناد أحمد بن محمد، قال: وقرأت على أبي الإخريط وهب بن و اضح مولى عبد العزيز بن أبي رواد وخبِرِني أنه قر أ على إسماعيل بن عبد الله، عـنـن عبد الله بن كثير عن مجاهد (r).

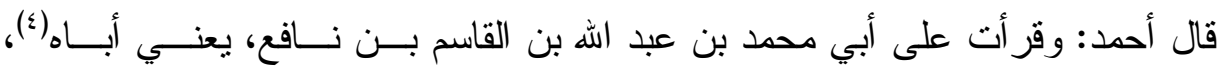

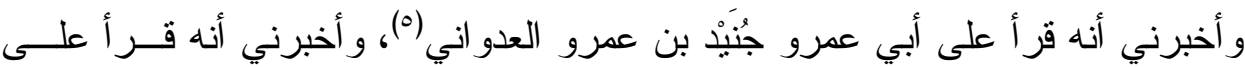

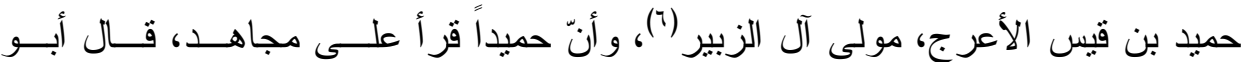
الحسن (v): هذه قر اعتتا و المجمع عليه عندنا.

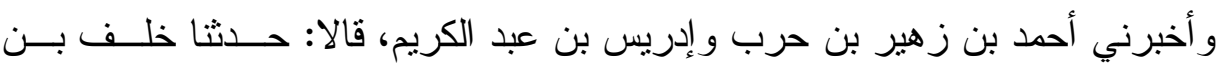

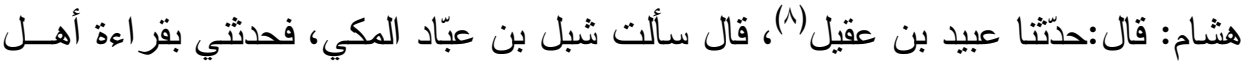

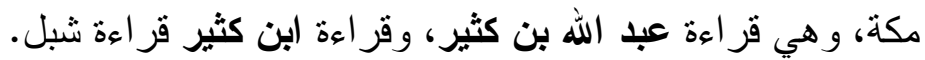

(·) كان إمام أهل مكة في القراءة بعد شبل، عرض على شبل و إسماعيل القسط، عرض عليه أحمد بن محمد البزي • ينظر : معرفة القراء

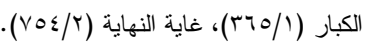

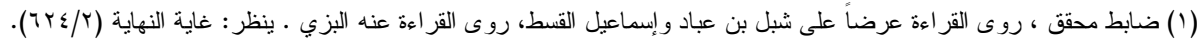

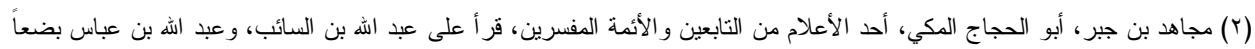

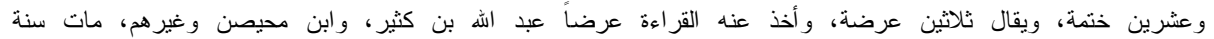

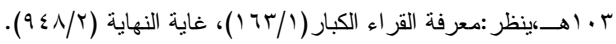

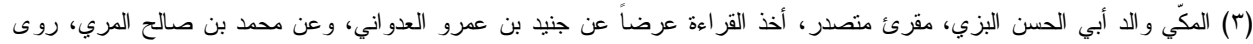

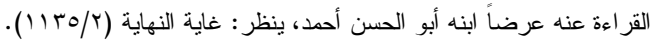

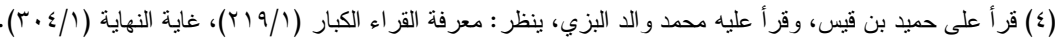

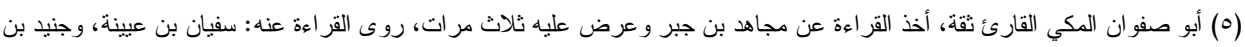

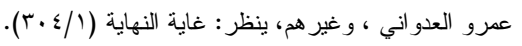

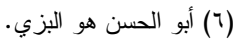

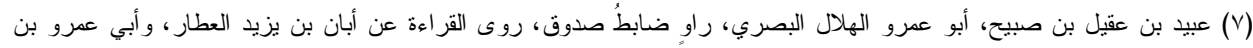

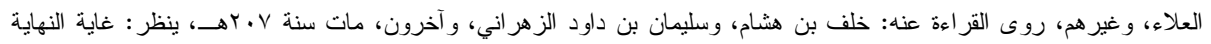


وحدثّي أبو محمد مضر بن محمد بن خالد بن الوليد، قال: حدثثا محمد بـن يحيـى

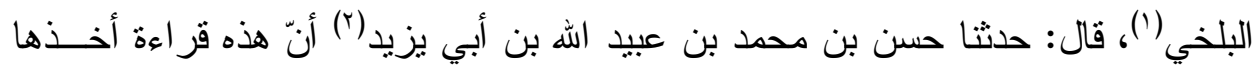

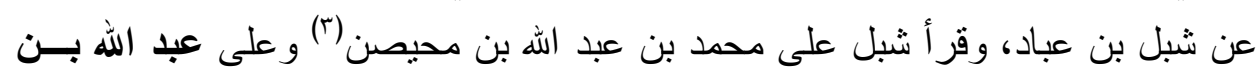

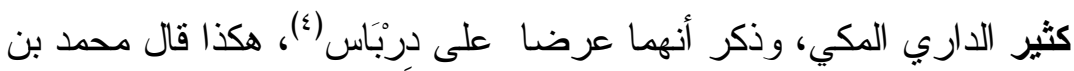
عبد الله بن محيصن، و الناس يقولون: محمد بن عبد الرحمن بن محيصن.

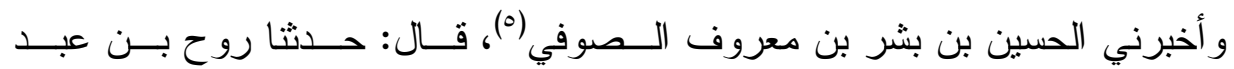

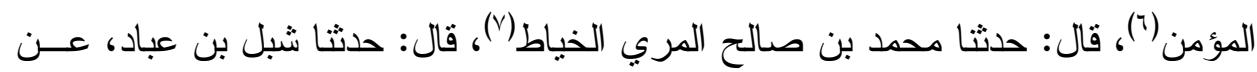

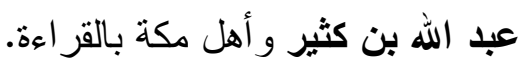

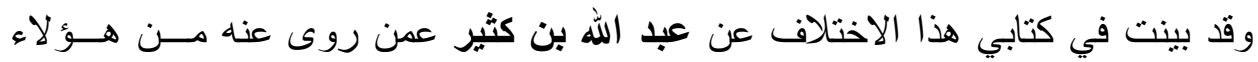
وغير هم في مو اضع الاختلاف (^). أندئ.

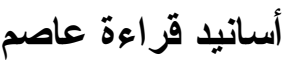
وما كان من قر اعة عاصم بن أبي النجود (9)، عن أبي بكر بن عياش.

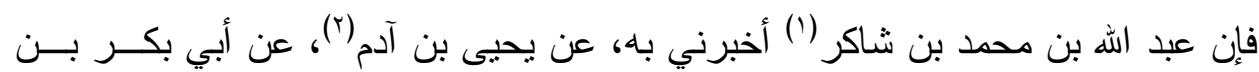

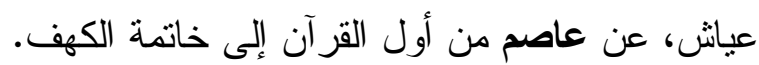

(^) كذا ورد اسمه في كتاب السبعة في القر اءات صبه ، و الصو اب أنّه حامد بن يحيى بن هانئ أ بو عبد الله البلخي، روى حروف أهل مكة

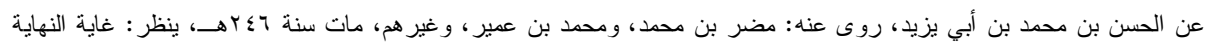
.$(\Gamma / Y / 1)$

(9) مقرئٌ متصدر ، قر أ على شبل بن عبّاد و ابن كثير ، و غير هم، روى القراءة عنه: حامد بن يحيى البلخي، و أحمد بن محمد بن أبي بزة،

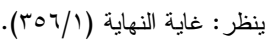

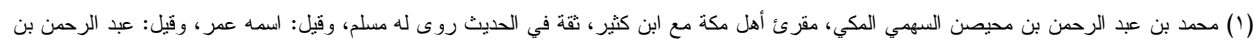

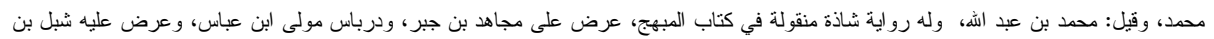

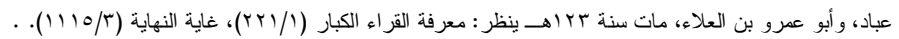

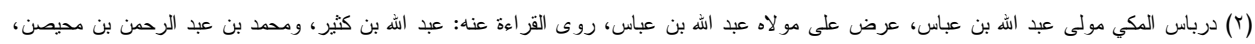

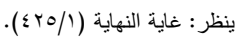

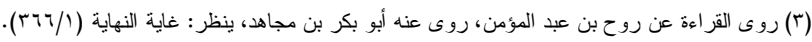

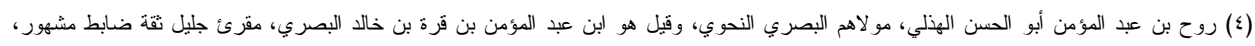

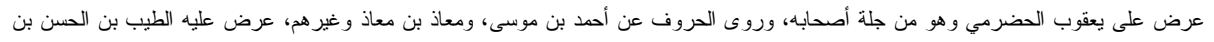

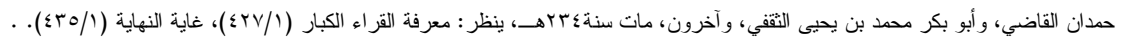

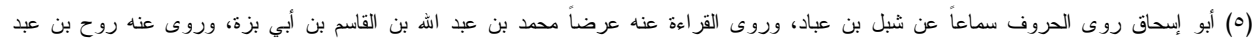

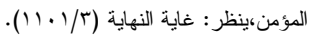

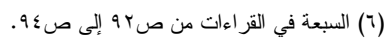

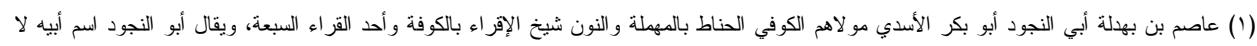

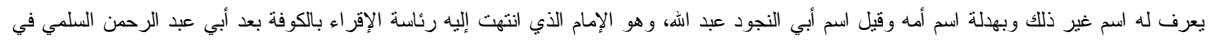

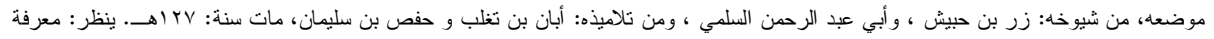




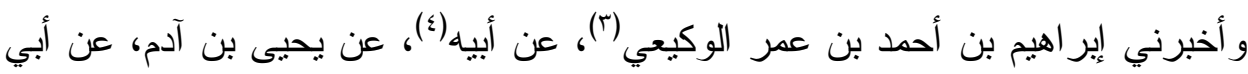
بكر ، عن عاصم، بذلك من أول القر آن إلى آخره.

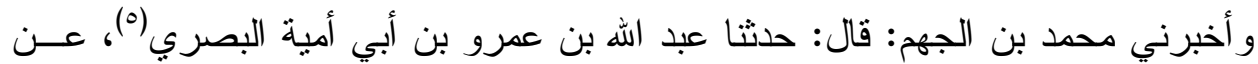
أبي بكر، عن عاصم، بذلك من أوله إلى آخره.

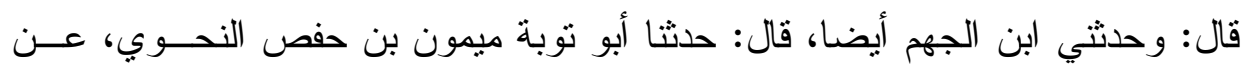

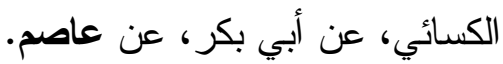

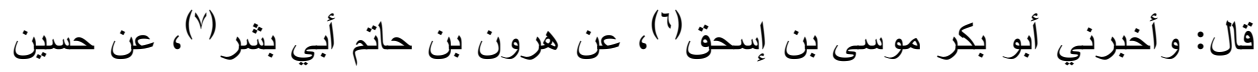

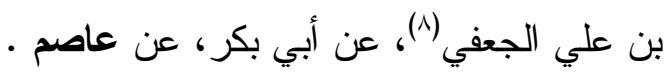

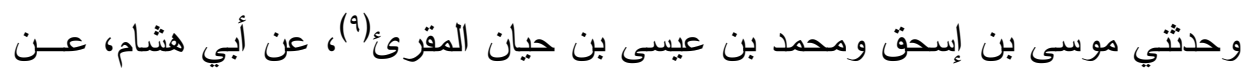

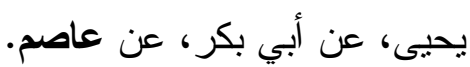
وحدثي الكسائي محمد بن بحيى، عنى عن أبي الحارث، عن أبي عمارة، عن حفـــ(·)،

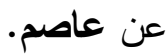

(r) هو عبد الله بن محمد بن شاكر أبو البختري العبدي البغدادي شيخ معروف ، من شيوخه: يحيى بن آدم ، ومن تلاميذه: ابن مجاهد وابن الأعر ابي وابن

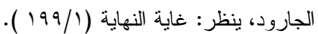

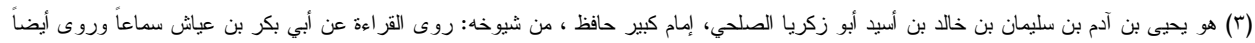

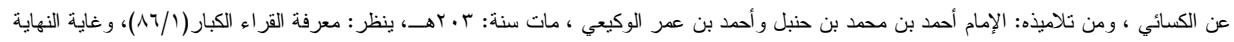

(ع) البغدادي مشهور ، من شيوخه: أبو بكر بن عياش ، ومن تلاميذه: أبو بكر بن مجاهد وجعفر بن أحمد الواسطي ، مات سنة: هوبهــ.

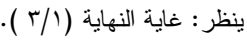

(0) هو أحمد بن عمر بن حفص الثيخ أبو إبر اهيم الوكيعي البغدادي الضرير ، من شيوخه: يحيى بن آدم ، ومن تلاميذه: ابنه إبر اهيم وعلي ) إني

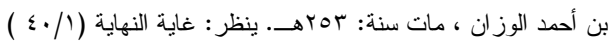
(7) نزيل الكوفة، وروى القراعة عن أبي بكر بن عاصم، روى عنه القز اعة روح بن عبد المؤمن، وأبو عبد الله محمد بن عبد الله بن هارون

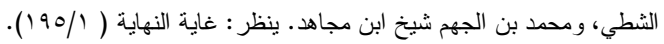

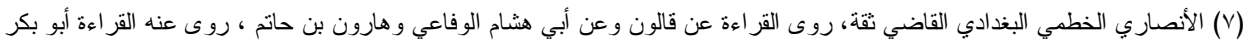

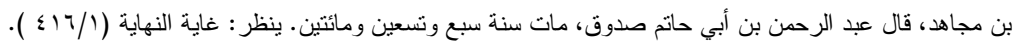

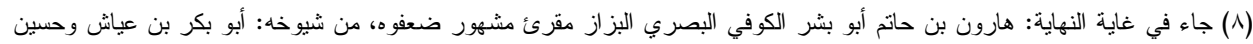

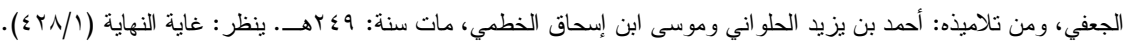
(9) أبو عبد اله الز اهد أحد الأعلام ، من شيوخه: حمزة و ؤأبو بكر بن عياش، ومن تلاميذه: أيوب بن المتوكل،و خلاد بن خالد، مات سنة:

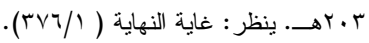
(1) أبو جعفر البغدادي شيخ، قال الداني مقرئ متصدر مشهور، من شيوخه: محمد بن يحيى القطعي و أبي هثام الرفاعي، ومن نلاميذه: ،

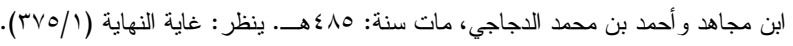

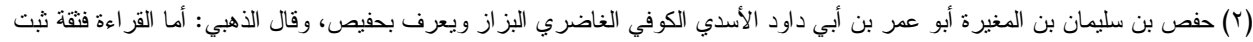

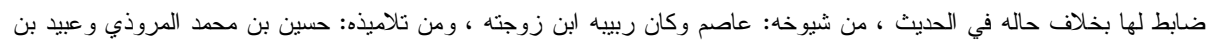

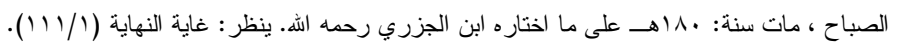


وحدثني أحمد بن علي الخزاز (') قال: حدثنا أبو عمر هبيرة بن محمد التمَّار (؟)، عـن عاهن حفص بن سليمان، عن عاصم.

وحدثي أبو محمد الرقي (r) عن أبي عمر، عن عن أبي عمارة، عن حفص، عن عاصم.

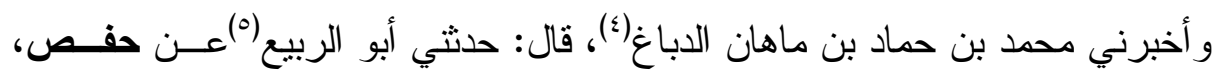

عن عاصم.

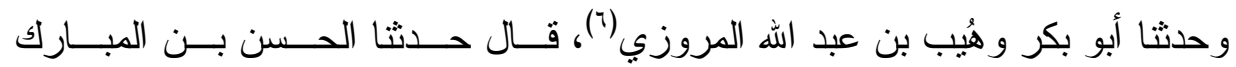

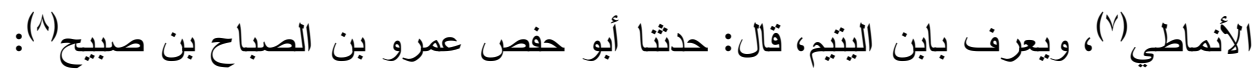

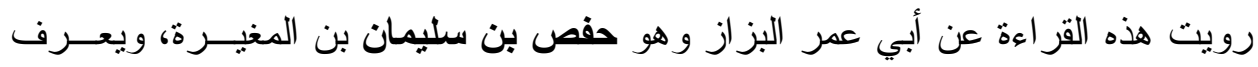

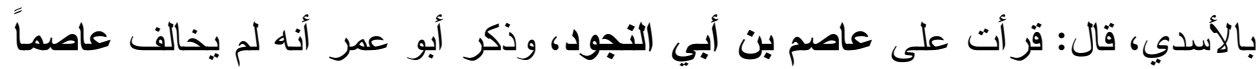

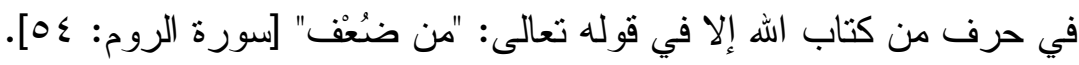

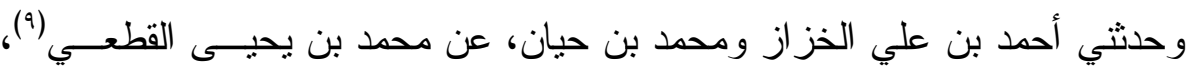

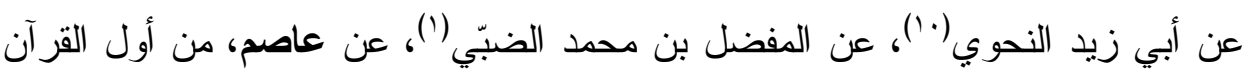
(r) أحمد بن علي بن الفضل أبو جعفر الخزاز بالخاء المجمة وزايين بغدادي مقرئٌ ماهر ثقة، من شيوخه: محمد بن يحبى القطعي وأبي

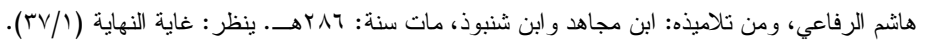

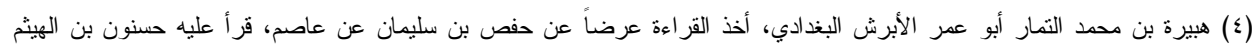

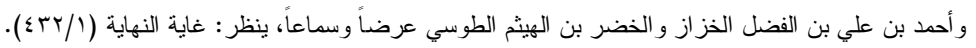

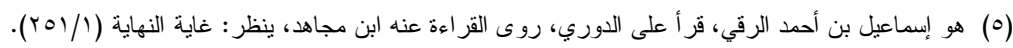

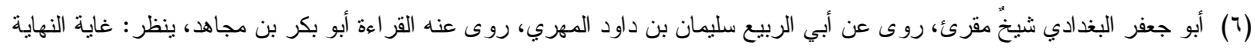

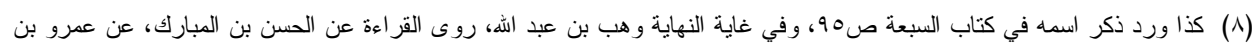

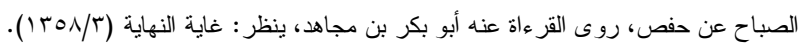

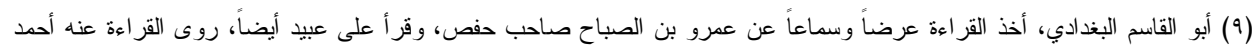

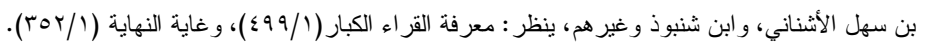

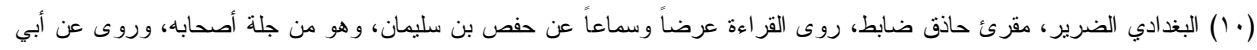

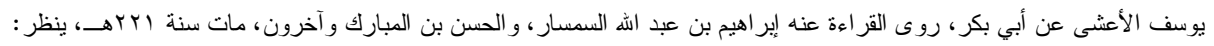

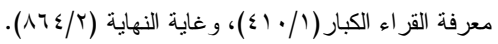

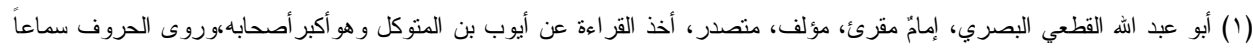

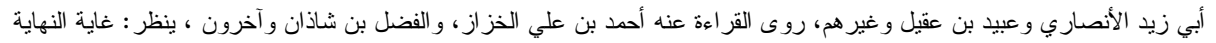


القرآن إلى خاتمة سورة آل عمر ان، حدثني به محمد بن حيان، ومن أول سورة النساء،

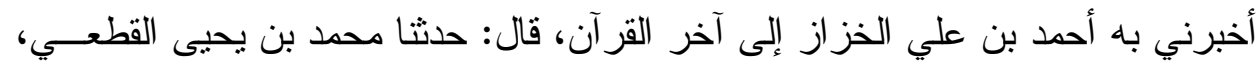

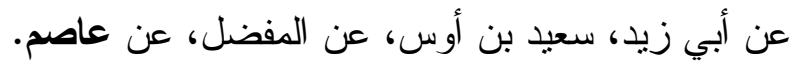

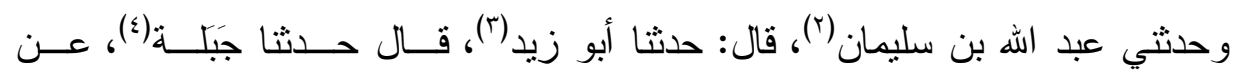

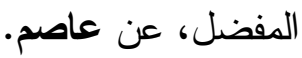
وحدثي غير واحد من أصحابنا عن أصحاب أبان، عن أبان(0) عن عاصم.

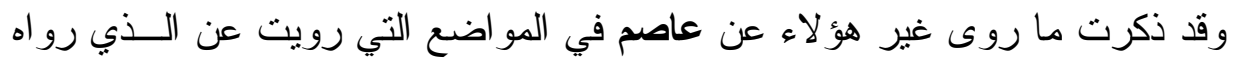

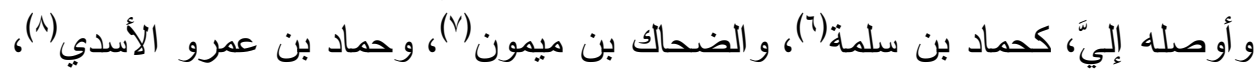

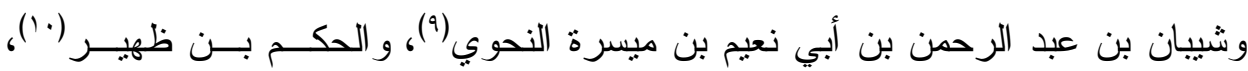

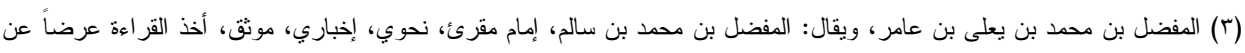

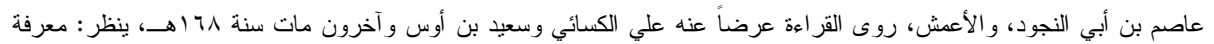

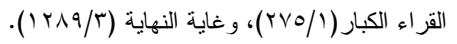

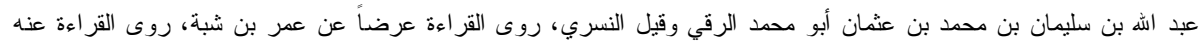

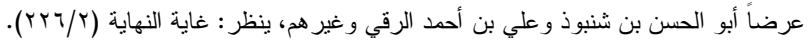

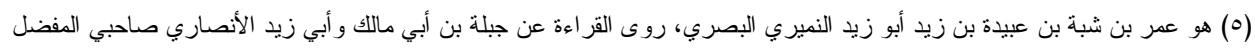

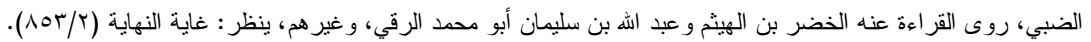

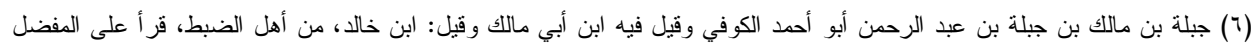

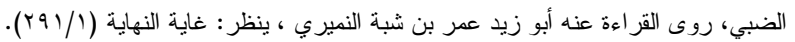

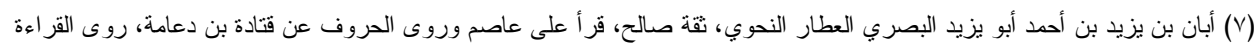

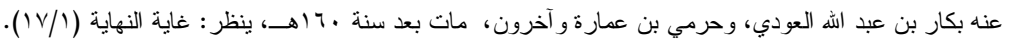

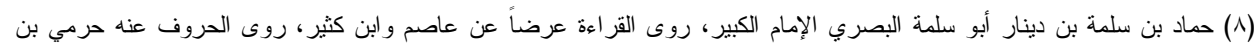

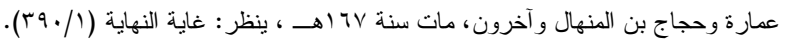

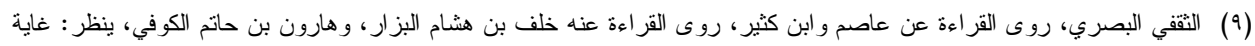

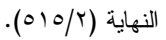

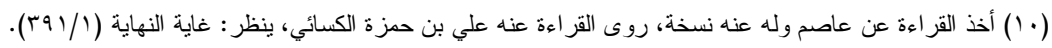

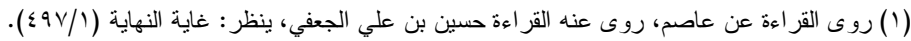

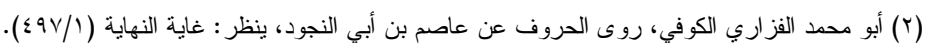




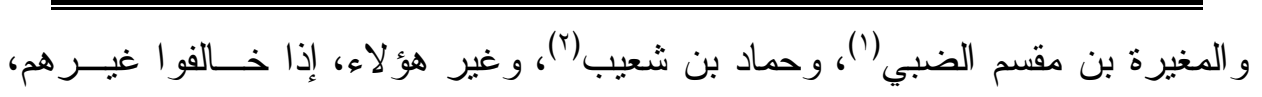

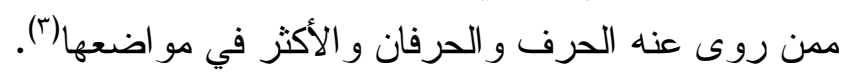

(r) أبو هاشم الكوفي الأعمى، روى القر اءة عن عاصم بن أبي النجود، وروى عن إير اهيم النخي، و أخذ عنه جرير بن عبد الحميد، مات

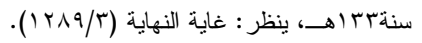

(ء) حماد بن أبي زياد شعيب أبو شعيب التميمي الحماني الكوفي، مقرئ جليل ضابط، أخذ القر اءة عرضاً عن عاصم، ولما مات عاصم قر أ

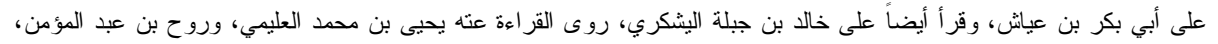

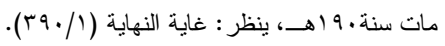

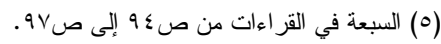


أسانيا قر اعة حمزة

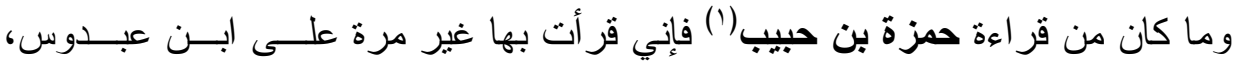

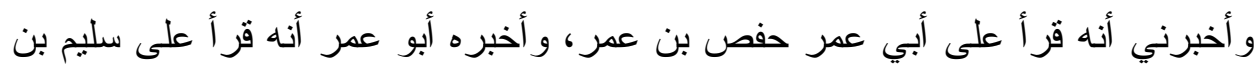

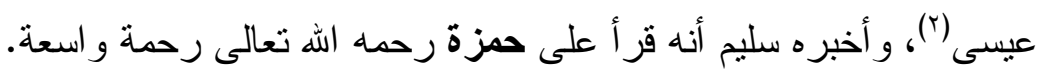
وأخبرني محمد بن الجهم قال حدثي خلف بن هثام عن سليم عن حمزة.

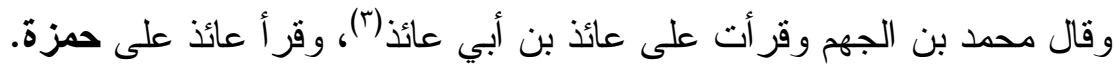
وأخبرني إدريس بن عبد الكريم، عن خلف، عن سليم عن حمزة.

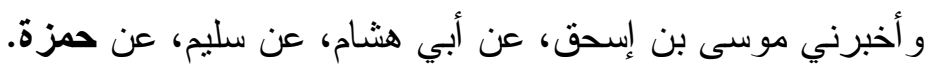

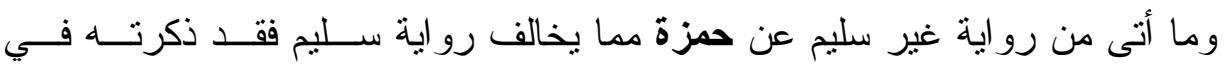

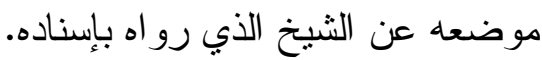

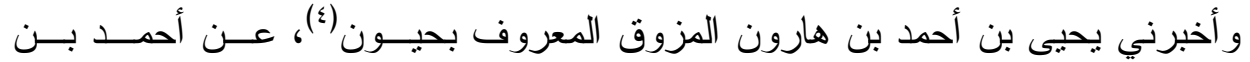

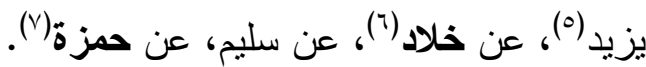
أساتيد قراعة الكسائي

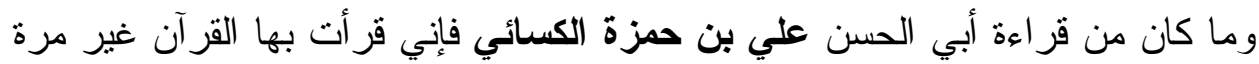

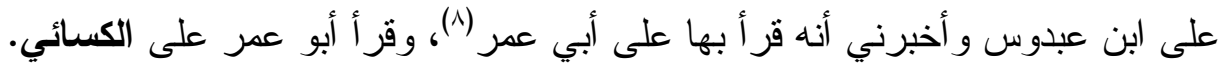

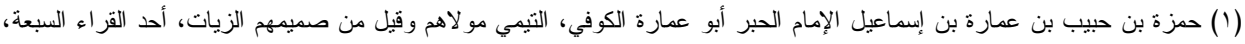

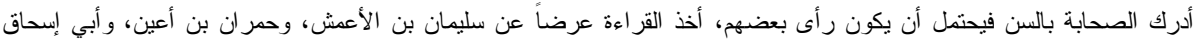

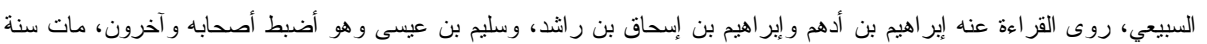

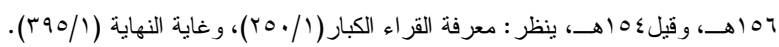

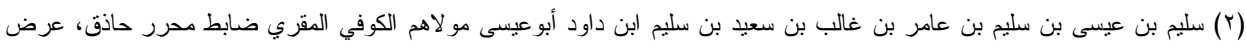

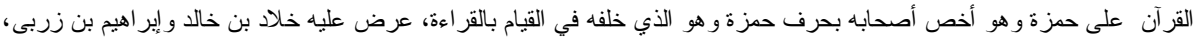

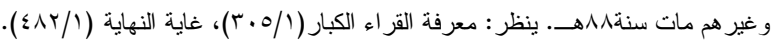

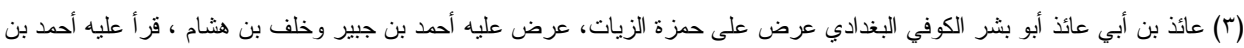

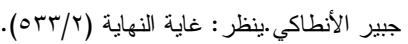

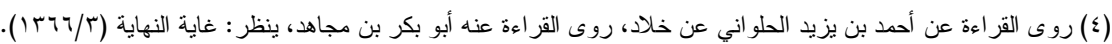

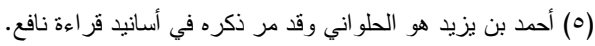

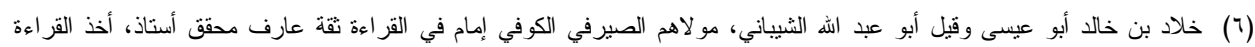

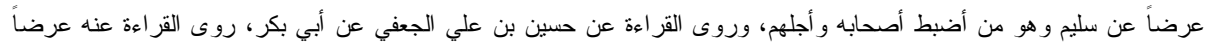

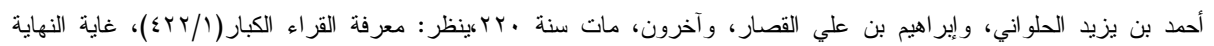

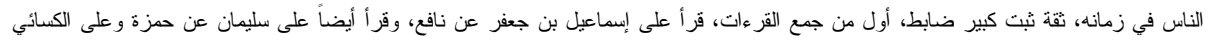


و أخبرني محمد بن يحيى الكسائي، عن أبي الحارث الليث بن خالد، عن الكسائي.

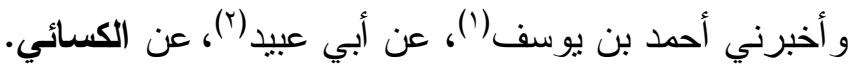

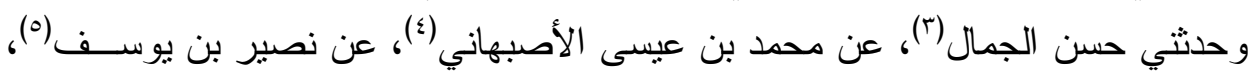
عن الكسائي.

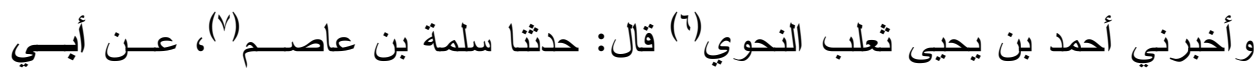
الحارث الليث بن خالد، عن الكسائي (^). أسانيد قراعة أبي عمرو بن العلاء

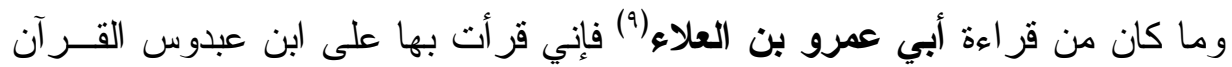

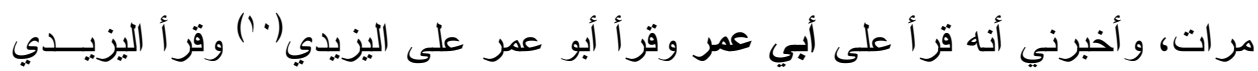
على أبي عمرو.

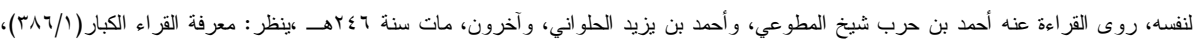

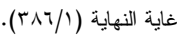

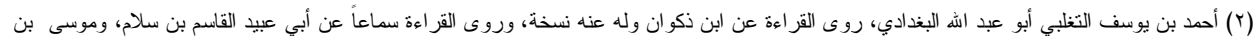

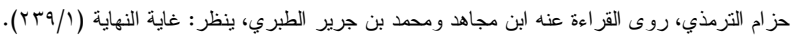

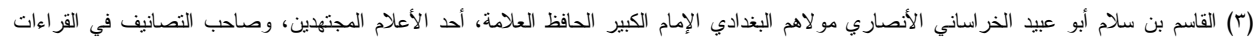

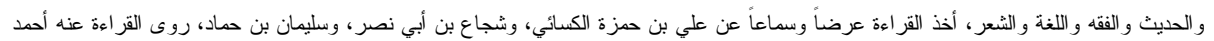

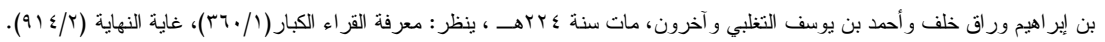

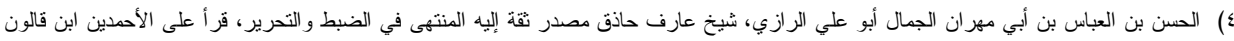

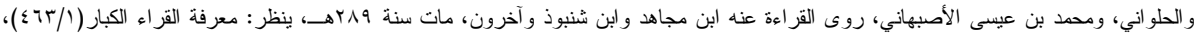

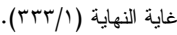

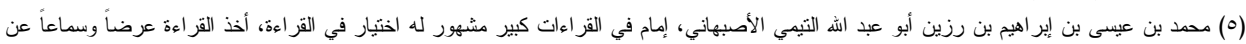

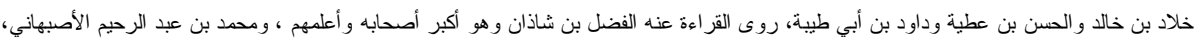

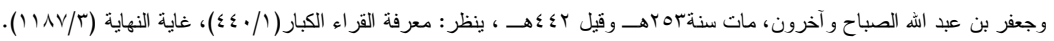

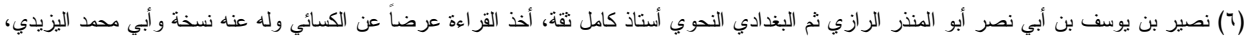

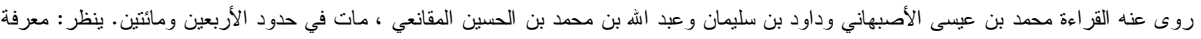

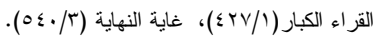

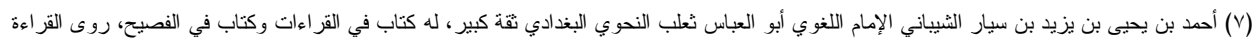

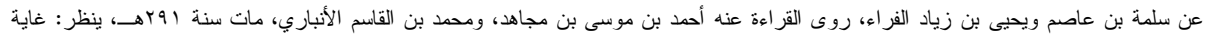

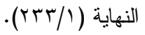

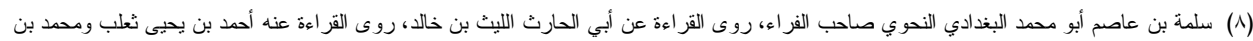

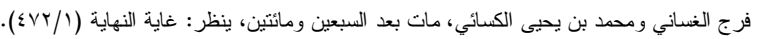

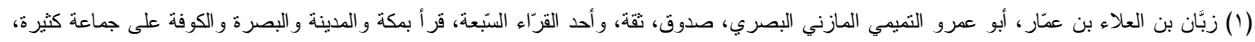

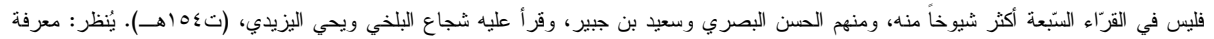

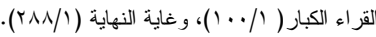

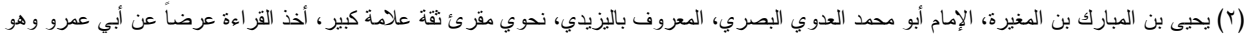

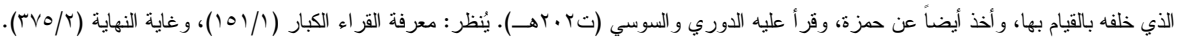




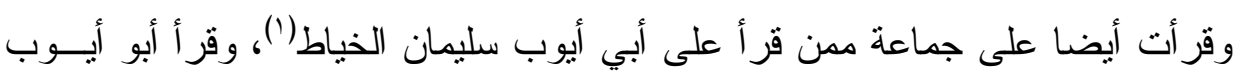
على اليزيدي.

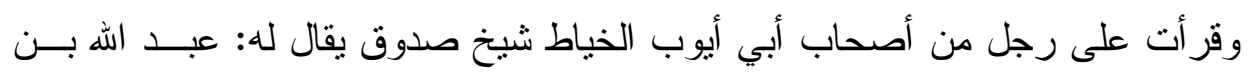

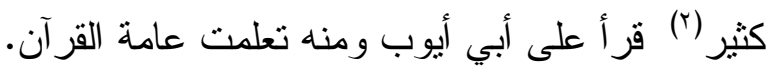

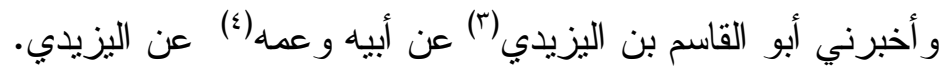

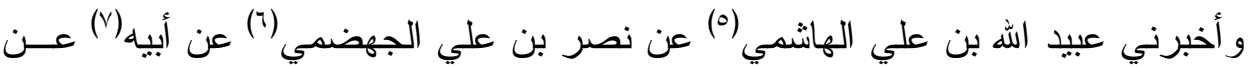
أبي عمرو.

و أخبرني أبو حانم الرازي(^) في كتابه إليّ عن أبي زيد الأنصاري عن أبي عمرو.

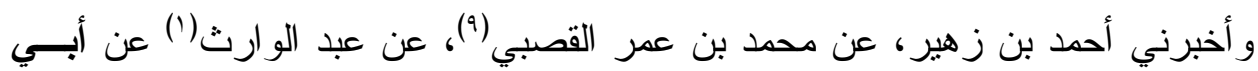

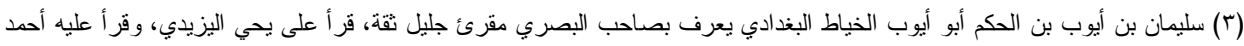

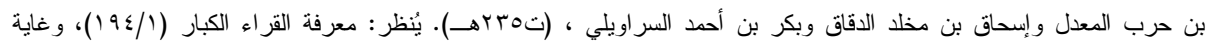

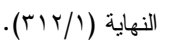

(ع) عبد الله بن كثير أبو محمد المؤدب البغدادي مقرئ يعرف بالصدوق، أخذ القراءة عرضاً عن أبي أيوب الخياط صاحب اليزيدي، روى

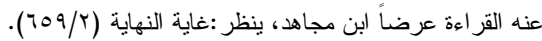

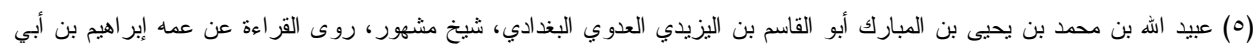

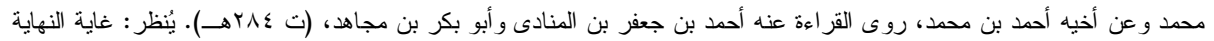

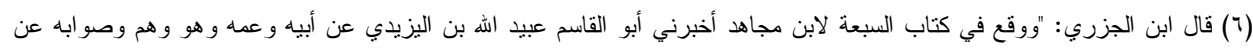

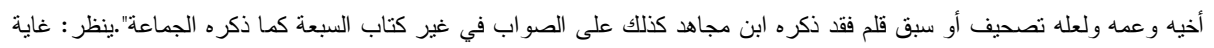

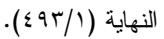
(V) عبيد اله بن علي بن الحسن أبو القاسم الهاشمي البغادي شيخ، روى الحروف عن نصر بن علي بن نصر عن أبيه عن أبي عمرو،

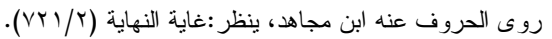

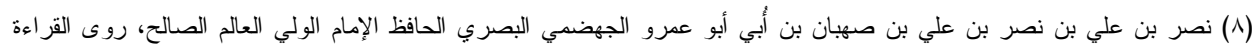

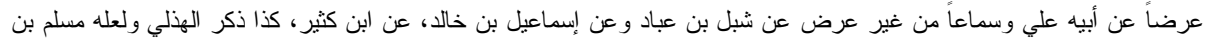

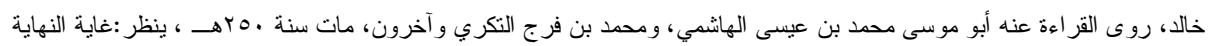
. (ITKV/T)

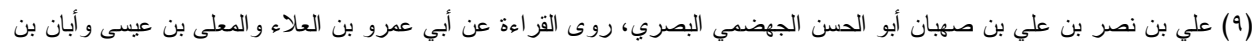

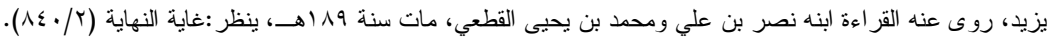

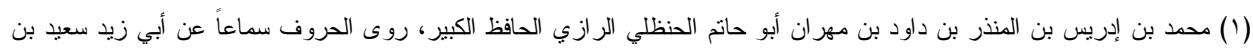

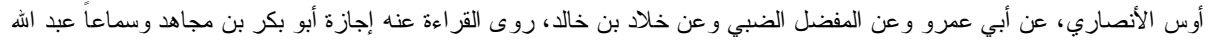

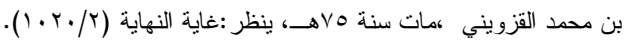

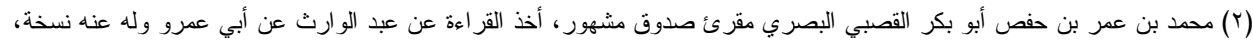

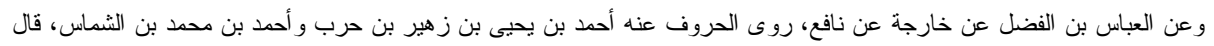

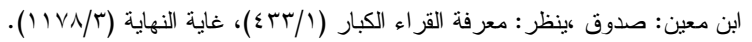


و أخبرني أحمد بن زهير أبي خيثمة، عن خلف، عن عبد الوهاب بن عطاء(؟)، عن أبي

و أخبرني أحمد بن أبي خيثمة، عن أبيه(ץ)، عن يونس المؤدب(๕)، عن هارون(*)، عـن أبي عمرو.

وحدثتا محمد ابن حيان، قال: حدثنا أبو هشام(آ، عن حسين، عن أبي عمرو.

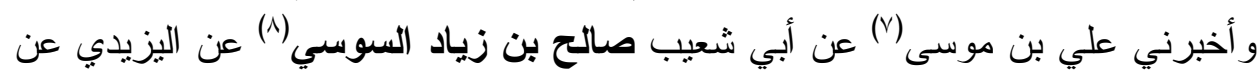

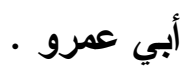

وحدثنا أحمد بن يوسف، عن أبي عبيد(9)، عن شجاع بن أبي نصر (')، عن أبي عمرو.

(r) عبد الوارث بن سعيد بن ذكوان أو عبيدة التنوري العنبري مولاهم البصري، إمام حافظ مقرئ ثقة، عرض القرآن على أبي عمرو

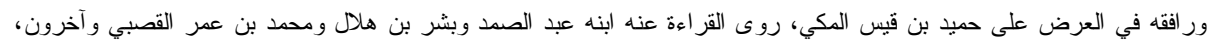

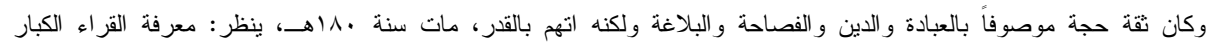

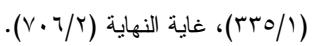

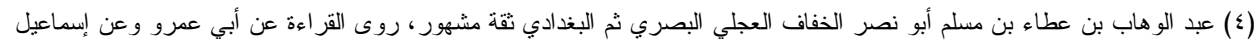

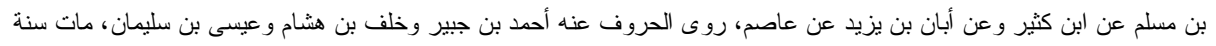

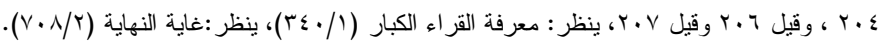

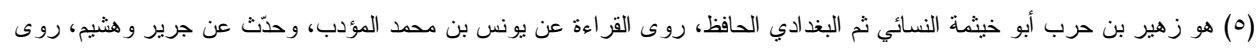

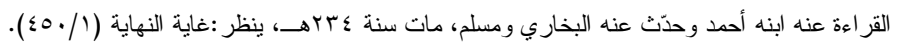

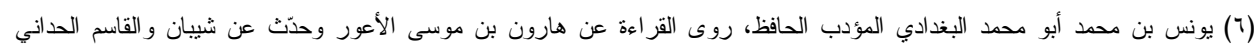

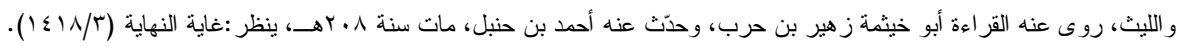

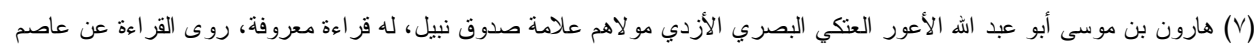

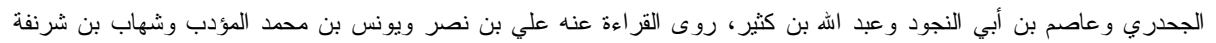

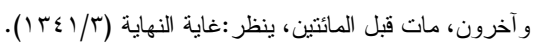

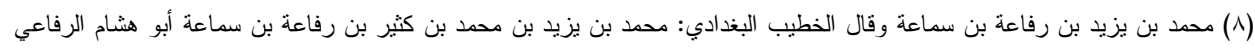

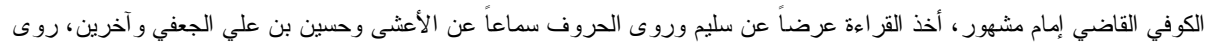

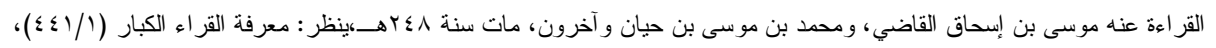

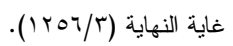

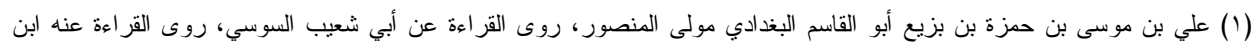

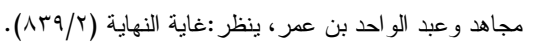

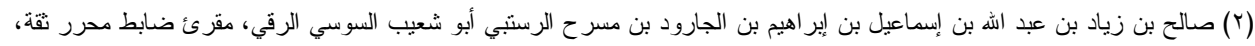

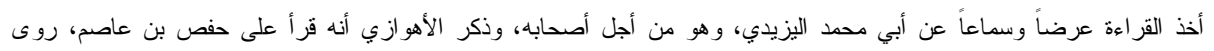

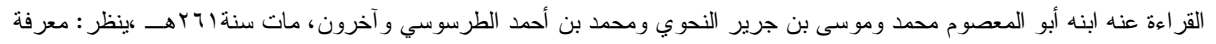


و أخبرني موسى بن إسحاق عن حسين، عن أبي عمرو.

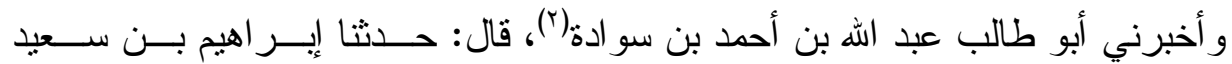
الزهر اني(r)، عن عبيد بن عقيل، عن أبي عمرو.

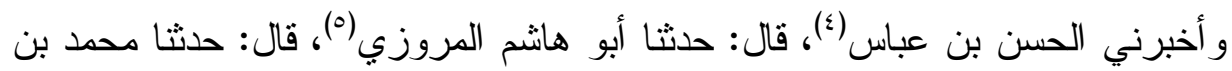

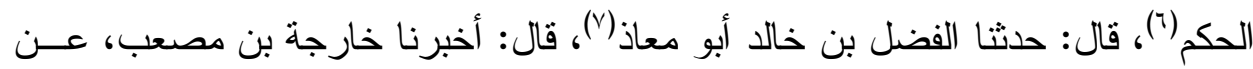
أبي عمرو ببعض القر اعة.

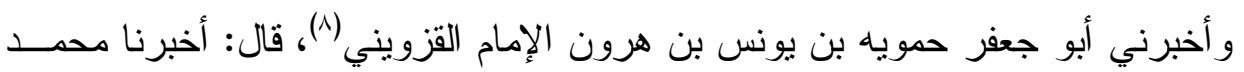

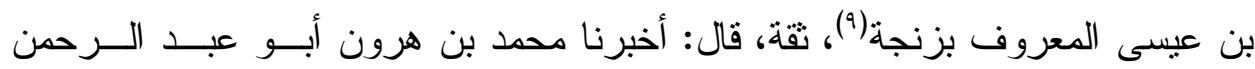

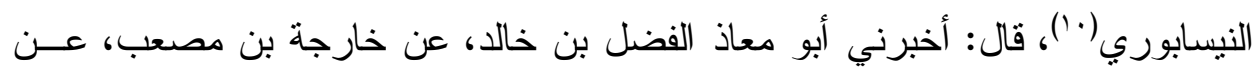
أبي عمرو بالقر اءة(')

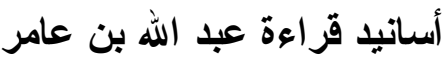

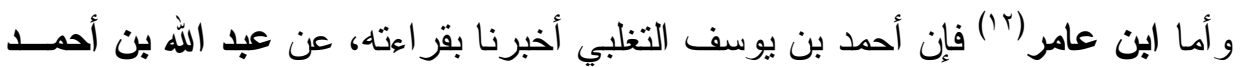

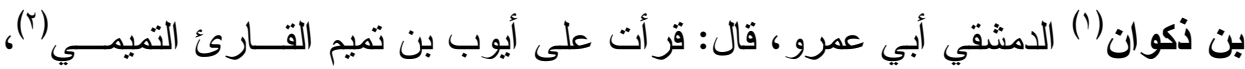

(؛) أبو نعيم البلخي ثم البخدادي الز اهد ثقة كبير سئل عنه الإمام أحمد فقال: بخ بخ وأين مثلك اليوم؟، عرض على أبي عمرو بن العلاء، وهو

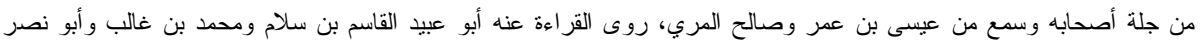

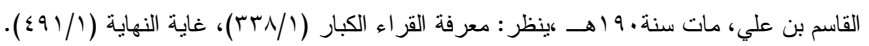

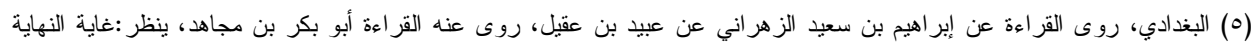

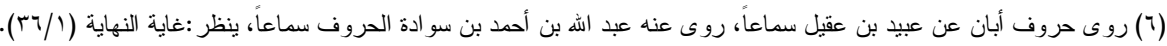

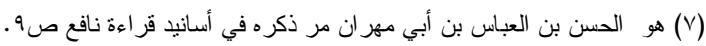

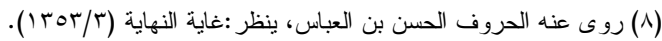

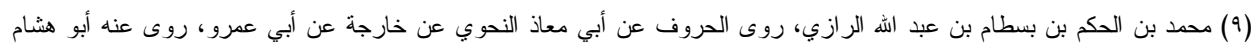

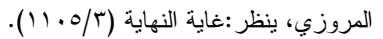

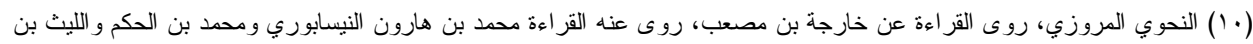

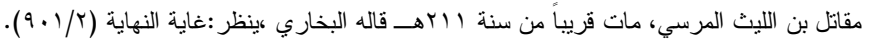

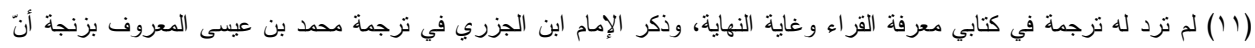

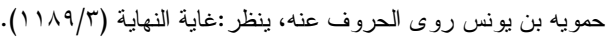

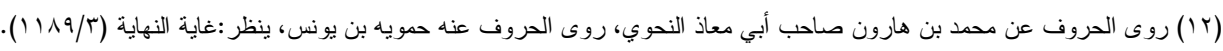

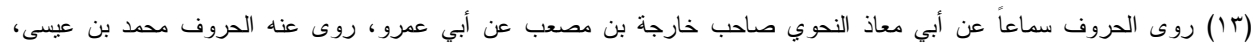

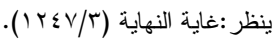

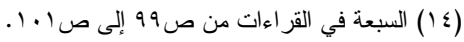

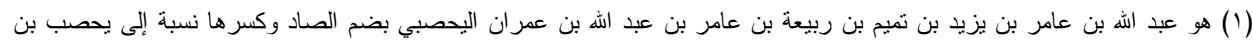

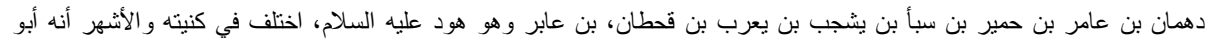


و أخبرني أيوب أنه قر أ على يحيى بن الحارث الذماري(ّ)، وأن يحيى بن الحارث قــر أ

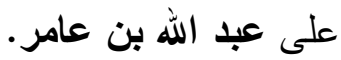
و أخبرنا أحمد بن محمد بن بكر (๕)، قال: حدثنا هشام بن عمار (0)، قال: حدثنا سويد بن

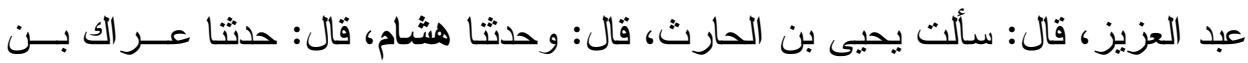

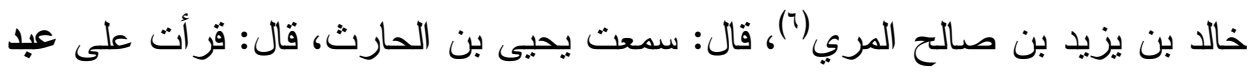
الله بن عامر.

عمر ان، إمام أهل الثام في القراءة و الذي انتهت إليه مشيخة الإقراء بها، أخذ القراءة عرضاً عن أبي الدرداء، وعن المغيرة بن أبي

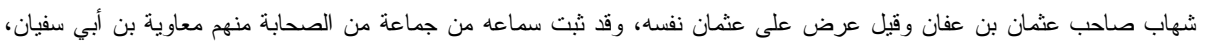

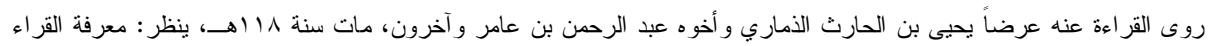

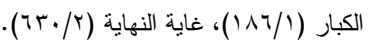

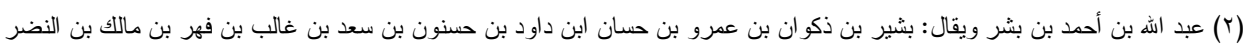

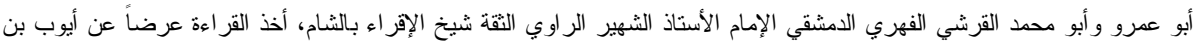

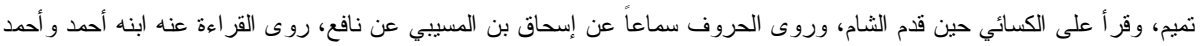

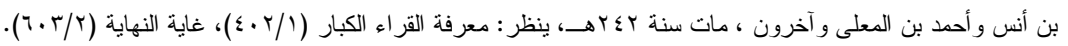

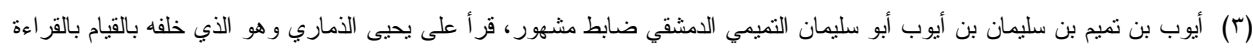

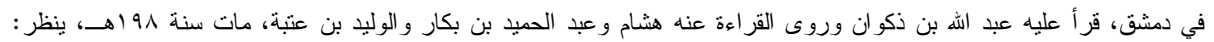

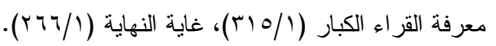

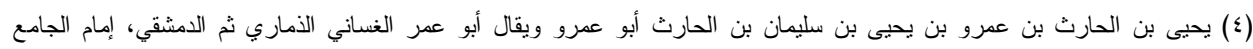

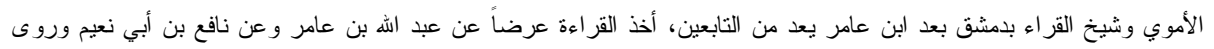

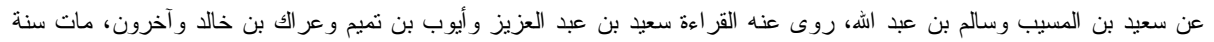

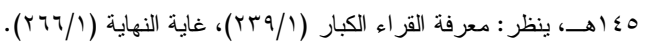

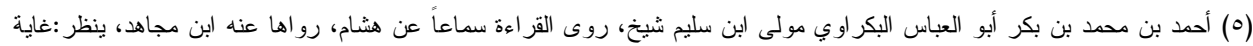

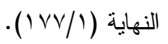

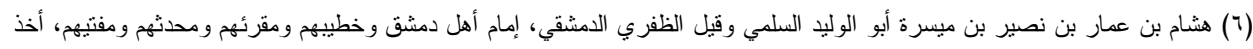

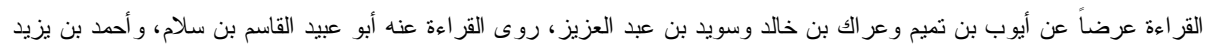

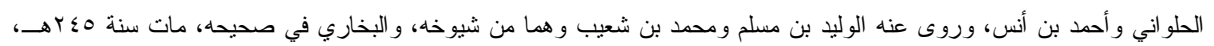

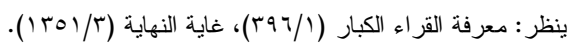

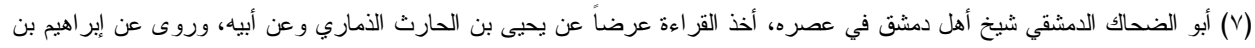

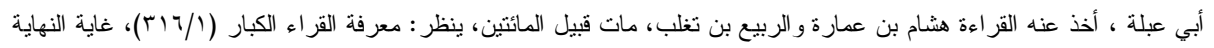




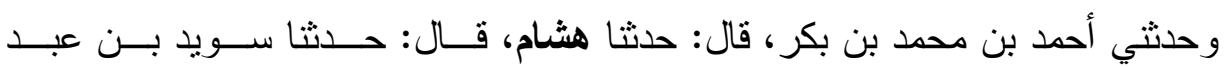

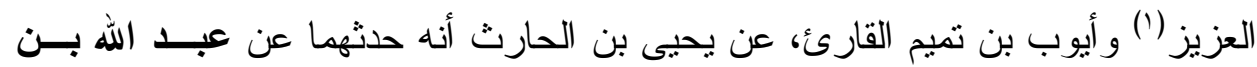

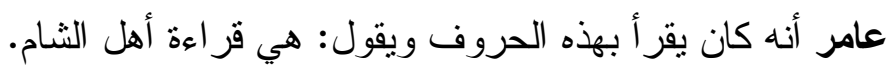

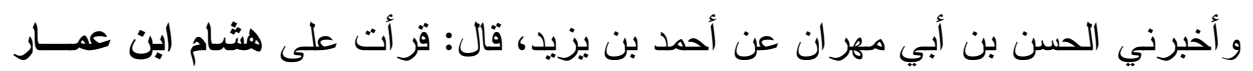
بهذه القر اعة بهذا الإسناد (r).

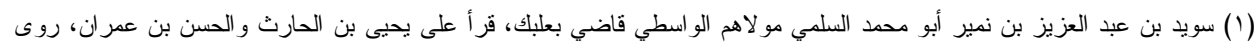

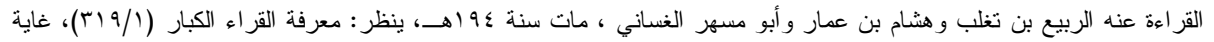




\section{المحور الثالث}

تمييز الطرق التي انتقاها الإمام ابن الجزري من طرق الكتاب

انتقى الإمام ابن الجزري من كتاب السبعة ستة طرق هي كالتالي:

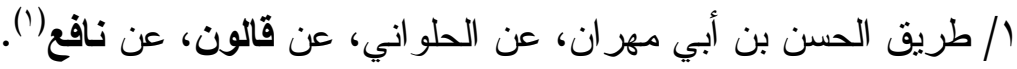

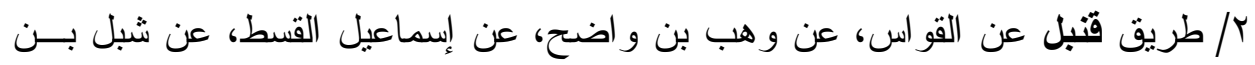

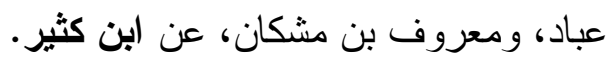

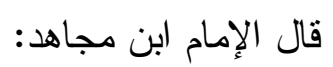

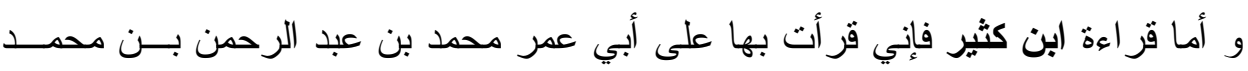

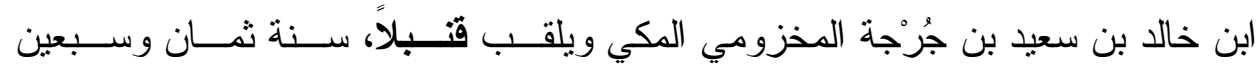

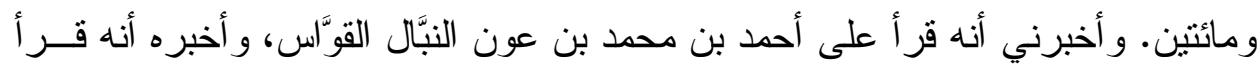

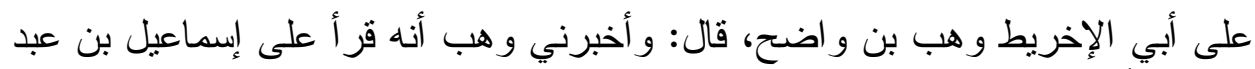

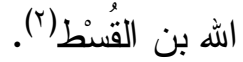
ب/ طريق أحمد بن بحيى ثعلب النحوي، عن سلمة بن عاصم، عن أبي الحارث الليــث بن خالد، عن الكسائي.

ع/ طريق محمد بن يحيى الكسائي، عن أبي الحارث الليث بن خالد، عن الكسائي(؟).

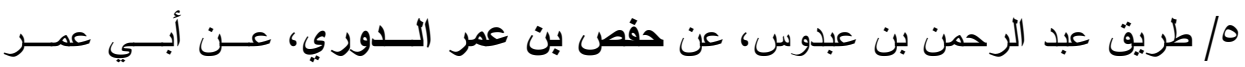
اليزيدي، عن أبي عمرو بن العلاء الرحن.

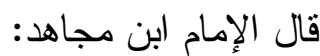

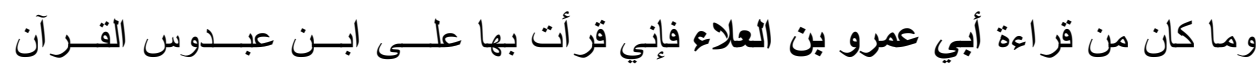

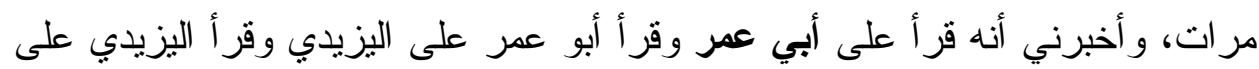

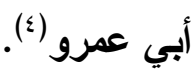

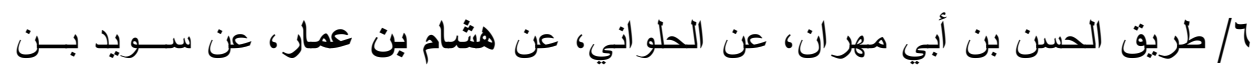

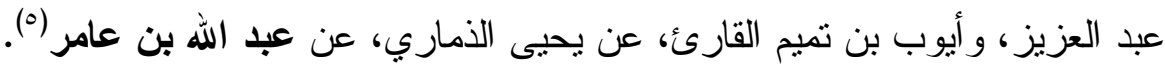

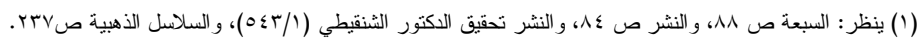

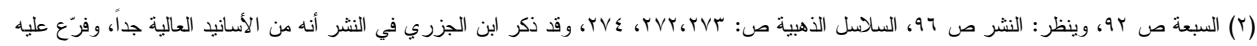
19 طريقاً من كتب مختلفة اعتمدت عليه.

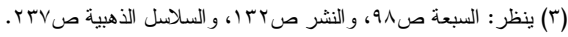

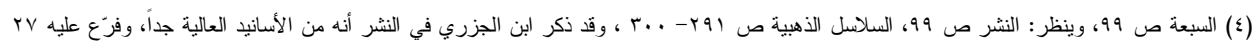




$$
\text { المحور الر ابع }
$$

منهج المصنف فيما ذكره من غير طرقه في الكتاب

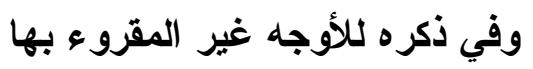

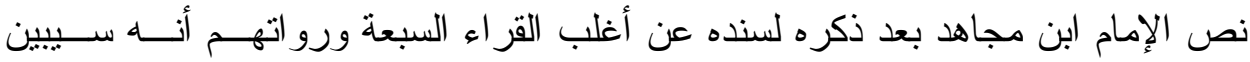

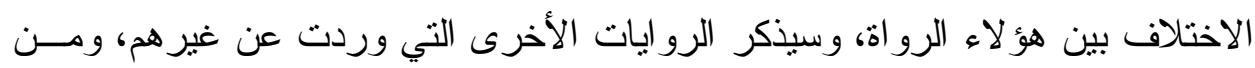

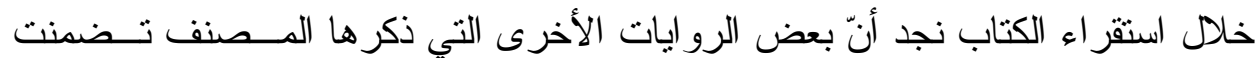

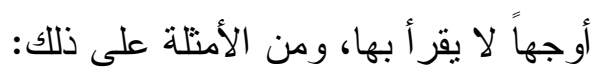

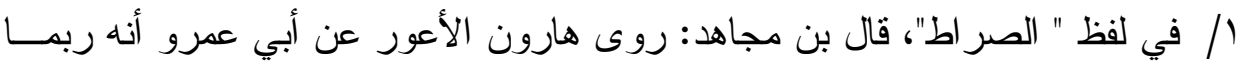

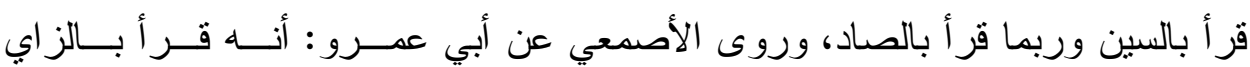

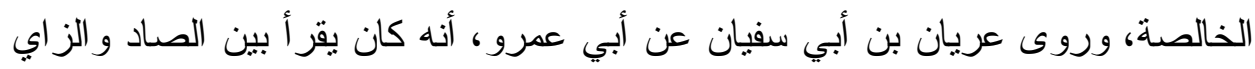

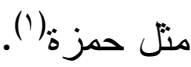
/ / في لفظ غير من قوله تعالى" غبر المغضوب عليهم"، قال ابن مجاهد: حــنـني أبــو

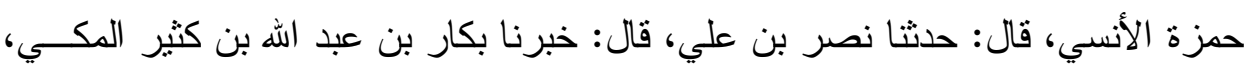

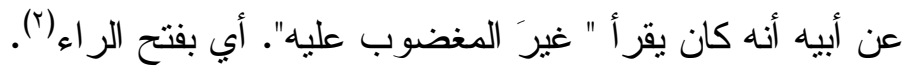




\section{الخاتمة}

وفي نهاية المطاف أحمد الله تعالى أن يسر لي إتمــام البحــث وهــــهـ جمـــة النتــائج و التوصيات التي توصلت إليها: النتائج: / / أهمية كتاب السبعة لابن مجاهد، ومنزلته، و علو إسناده، و اعتماد العلماء عليه.

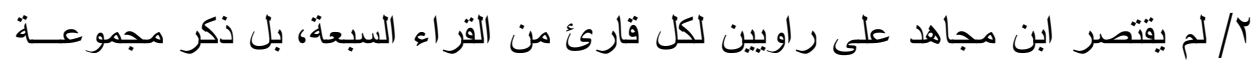
كبيرة من رواة القر اء. r/ عظمة كتاب النشر ودوره الكبير في در اسة الأسانيد وتمحيصها.

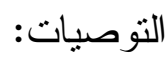
/ / العناية بكتاب السبعة و إعادة تحقيقه، و إخر اج مسائله، وتمبيــز رو اياتــه، ودر اســـة أسانيده در اسة جيدة ودقيقة. r/ البحث عن مخطوطات كتب طبقات القر اء، وتحقيقها.

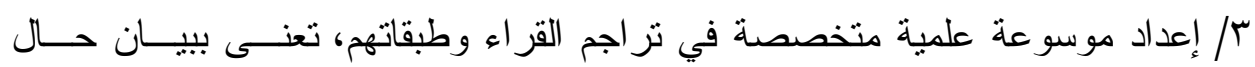
الرو اة.

ع / إضافة مقررٍ لدر اسة أسانيد القر اءات در اسة و افية ضمن مقررات الدر اسات العليا.

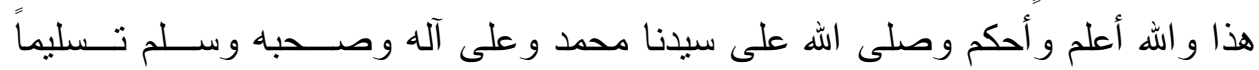
كثيرًا. 
فهرس المصادر والمراجع:

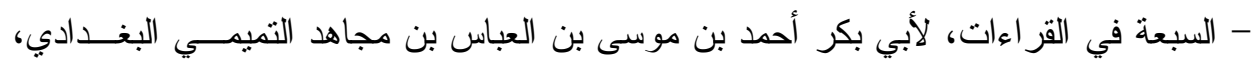

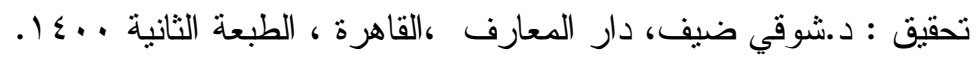
- السلاسل الذهبية بالأسانيد النشرية من شيوخي إلى الحضرة النبوية، إعداد: الــدكتور أيمـن

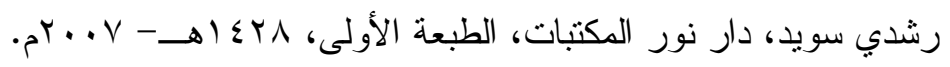

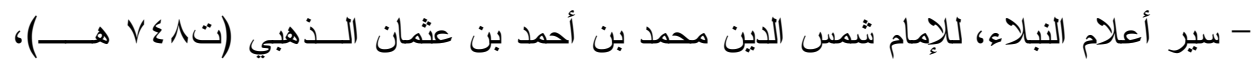
تحقيق: شعيب الأرناؤوط، النانشر : مؤسسة الرسالة.

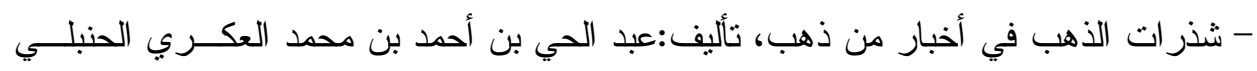

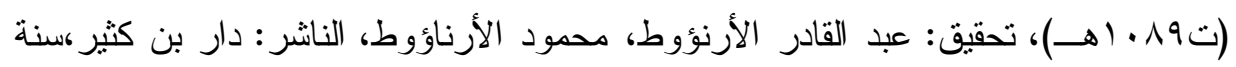

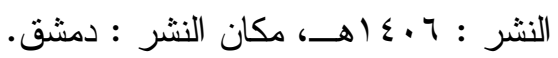

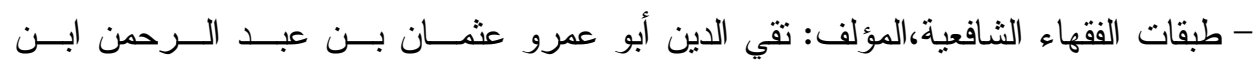
الصلاح(ت آجهـ)، تحقيق : محيي الدين علي نجيب، النانر : دار البشائر الإسلامية،سنة

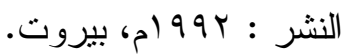

- العبر في خبر من غبر، لأبي عبداله محمد بن أحمد بن عثمان بن قايماز الذهبي، المحقق : أبو هاجر محمد السعيد بن بسيوني زغلول، الناشر : دار الكتب العلمية ، بيروت.

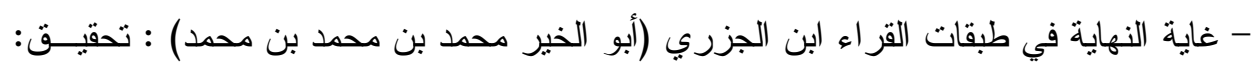

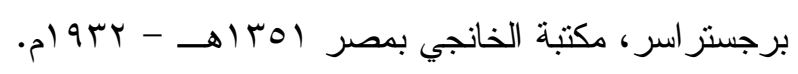

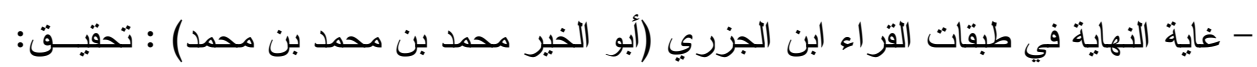

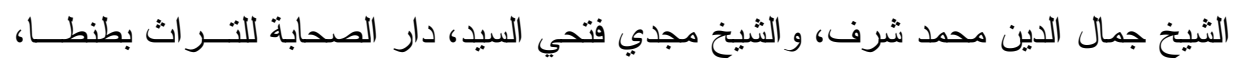

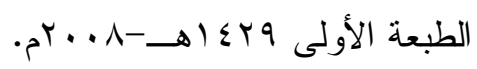

- معجم المؤلفين نز اجم مصنفي الكتب العربية، عمر رضا كحالة، مؤسسة الرسالة.

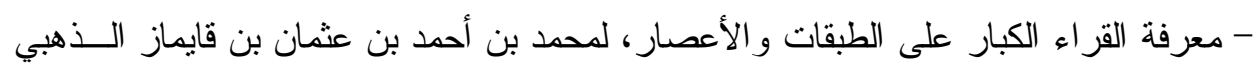

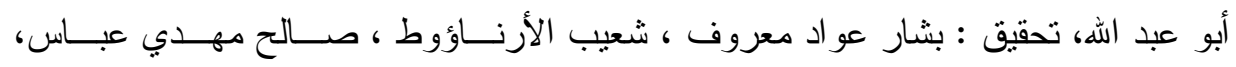

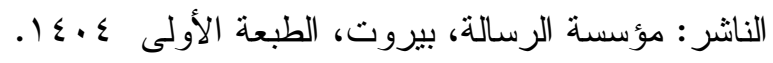

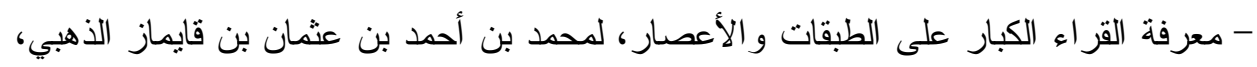

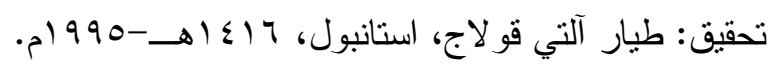


- المنتظم في تاريخ الملوك و الأمم، عبد الرحمن بن علي بن محمد بن الجوزي أبـــو الفــرج،

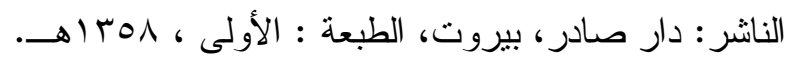

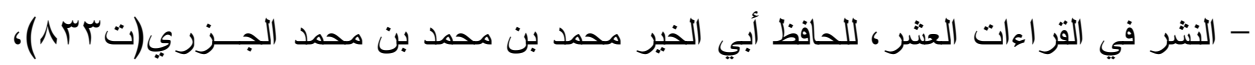

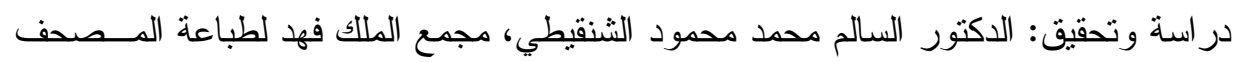

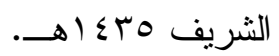

- النشر في القراءات العشر ، ابن الجزري (أبو الخبر محمد بن محمد بــن محمــد)، المكتبــة

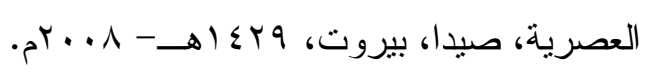


